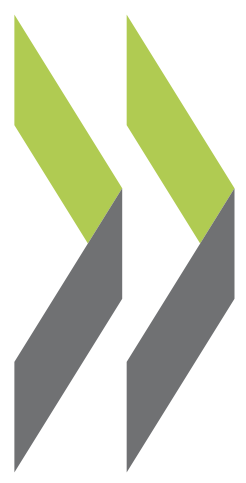

OECD Economics Department Working Papers No. 1122

Tackling Labour Mismatches and Promoting Mobility Stéphane Sorbe in Hungary 
Organisation de Coopération et de Développement Économiques

Organisation for Economic Co-operation and Development

04-Jun-2014

ECONOMICS DEPARTMENT

English - Or. English

TACKLING LABOUR MISMATCHES AND PROMOTING MOBILITY IN HUNGARY

ECONOMICS DEPARTMENT WORKING PAPERS No. 1122

By Stéphane Sorbe

OECD Working Papers should not be reported as representing the official views of the OECD or of its member countries. The opinions expressed and arguments employed are those of the author(s).

Authorised for publication by Alvaro Pereira, Director, Country Studies Branch, Economics Department.

All Economics Department Working Papers are available through OECD's Internet website at http://www.oecd.org/eco/workingpapers

JT03358718

Complete document available on OLIS in its original format

This document and any map included herein are without prejudice to the status of or sovereignty over any territory, to the delimitation of international frontiers and boundaries and to the name of any territory, city or area. 
ECO/WKP(2014)18

OECD Working Papers should not be reported as representing the official views of the OECD or of its member countries. The opinions expressed and arguments employed are those of the author(s).

Working Papers describe preliminary results or research in progress by the author(s) and are published to stimulate discussion on a broad range of issues on which the OECD works.

Comments on Working Papers are welcomed, and may be sent to the Economics Department, OECD, 2 rue André-Pascal, 75775 Paris Cedex 16, France, or by e-mail to eco.contact@oecd.org.

This document and any map included herein are without prejudice to the status of or sovereignty over any territory, to the delimitation of international frontiers and boundaries and to the name of any territory, city or area.

The statistical data for Israel are supplied by and under the responsibility of the relevant Israeli authorities. The use of such data by the OECD is without prejudice to the status of the Golan Heights, East Jerusalem and Israeli settlements in the West Bank under the terms of international law.

You can copy, download or print OECD content for your own use, and you can include excerpts from OECD publications, databases and multimedia products in your own documents, presentations, blogs, websites and teaching materials, provided that suitable acknowledgment of OECD as source and copyright owner is given. All requests for commercial use and translation rights should be submitted torights@oecd.org. 
ECO/WKP(2014)18

\section{ABSTRACT/RÉSUMÉ \\ Tackling labour mismatches and promoting mobility in Hungary}

Significant labour market mismatches and insufficient mobility penalise employment and productivity. Mismatches have above all a skills dimension, with an excess of low-skilled workers and a possible lack of skilled workers in certain domains. Reducing the high tax wedge on low salaries and avoiding excessive minimum wage increases would support demand for low-skilled labour. In the longer term, upgrading the labour supply requires improving educational outcomes, especially of disadvantaged students, and making the school-to-work transition less abrupt. To facilitate good matching and enhance sectoral mobility, a somewhat longer duration of unemployment benefits and an upscaled Public Employment Service would be of value, as well as greater focus on reintegration in the public works programme and more efficient and developed lifelong learning. Besides skills mismatches, important geographic mismatches are illustrated by high and persistent regional disparities in the unemployment rate. Mobility is hampered by the underdevelopment of the rental housing market, while there is room to enhance the efficiency of public transport to further support commuting.

This Working Paper relates to the 2014 OECD Economic Survey of Hungary (www.oecd.org/eco/surveys/economic-survey-hungary.htm).

JEL classification: J24, J61, J64, I28

Keywords: Hungary, labour mismatches, skills, tax wedge, public works, education, housing, transport

$* * * * * * *$

\section{Améliorer l'adéquation offre-demande de travail et promouvoir la mobilité en Hongrie}

D'importants déséquilibres du marché du travail et une mobilité insuffisante pénalisent l'emploi et la productivité. Les inadéquations de main d'œuvre concernent surtout les compétences, avec un excès de travailleurs peu qualifiés et un possible manque de travailleurs qualifiés dans certains domaines. Réduire le coin fiscal élevé sur les bas salaires et éviter des augmentations excessives du salaire minimum soutiendraient la demande de main-d'œuvre peu qualifiée. À plus long terme, la mise à niveau de l'offre de travail passe par l'amélioration des résultats scolaires, en particulier des étudiants défavorisés, et par une transition moins abrupte des études à l'emploi. Pour faciliter une bonne allocation de main d'œuvre et d'améliorer la mobilité sectorielle, une durée un peu plus longue des prestations de chômage et un meilleur Service public de l'emploi seraient utiles, ainsi qu'un accent plus prononcé sur la réintégration dans le programme de travaux publics et une formation continue plus efficace et mieux développée. Outre l'inadéquation des compétences, d'importants déséquilibres géographiques sont illustrés par la persistance de fortes disparités régionales du taux de chômage. La mobilité est entravée par le sous-développement du marché du logement locatif et il serait possible d'améliorer l'efficacité des transports publics pour davantage encourager les déplacements domicile-travail.

Ce Document de travail se rapporte à l'Étude économique de l'OCDE de la Hongrie, 2014 (www.oecd.org/fr/eco/etudes/etude-economique-hongrie.htm).

Classification JEL : J24, J61, J64, I28

Mots clefs : Hongrie, marche du travail, compétences, coin fiscal, travaux publics, éducation, logement, transport 


\section{TABLE OF CONTENTS}

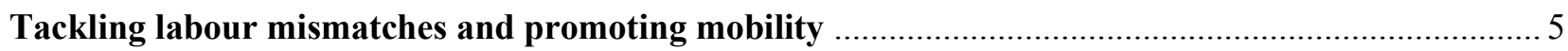

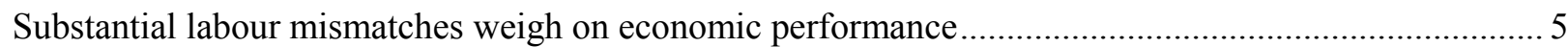

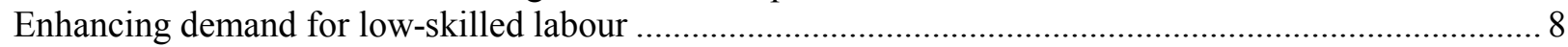

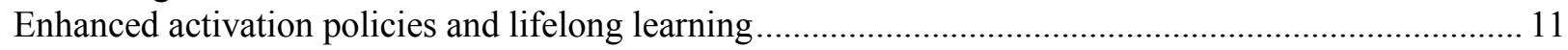

Improving initial education to match labour market needs ................................................................... 15

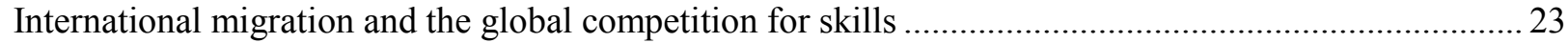

A more flexible housing market would facilitate the relocation of workers .......................................... 25

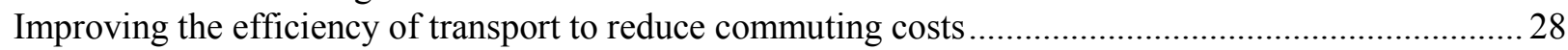

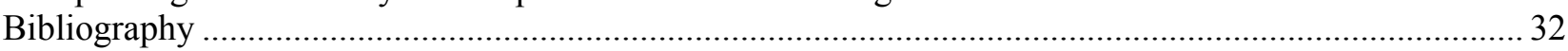

\section{Tables}

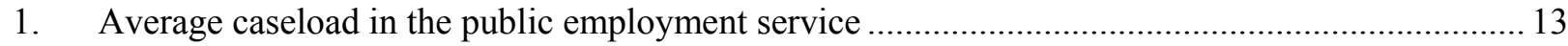

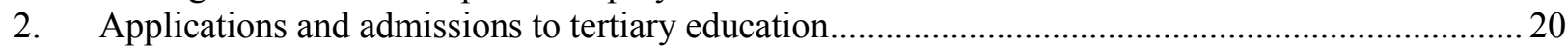

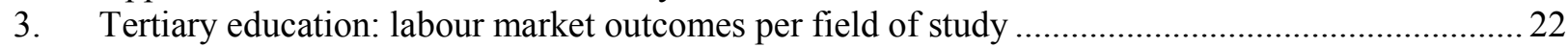

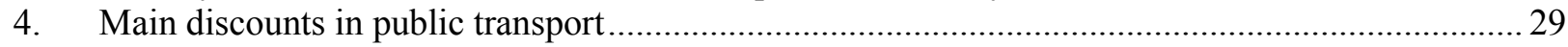

\section{Figures}

1. Employment and labour productivity growth have been low ….............................................. 5

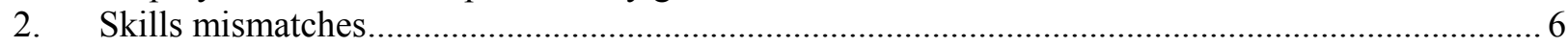

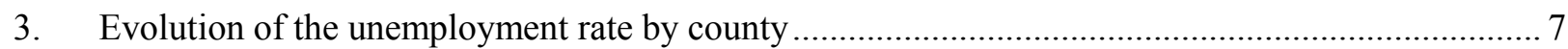

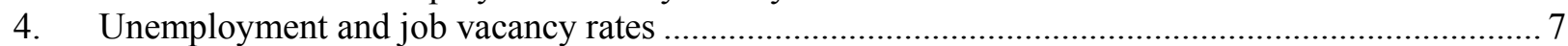

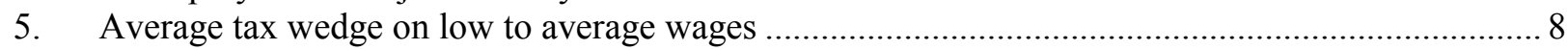

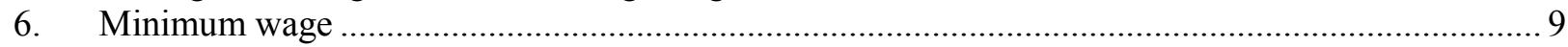

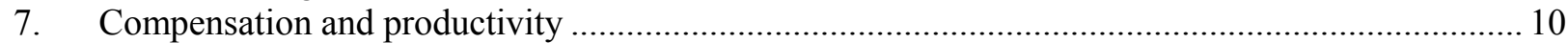

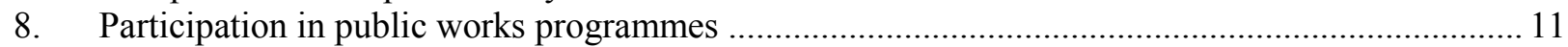

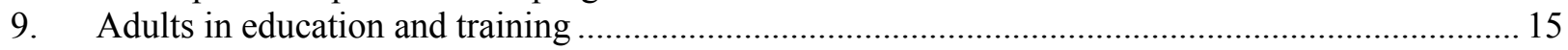

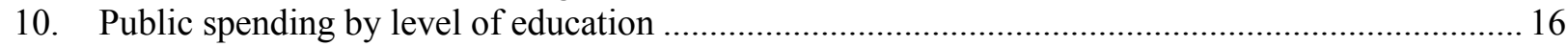

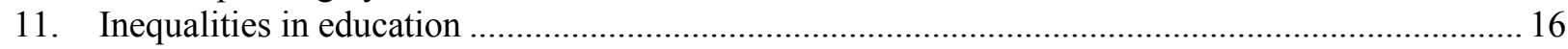

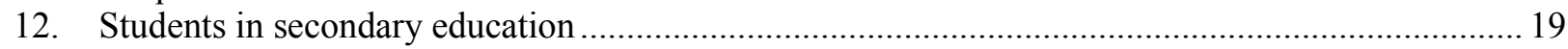

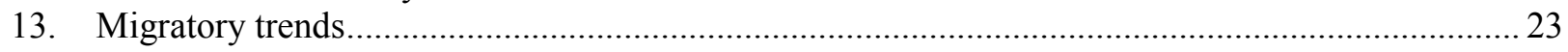

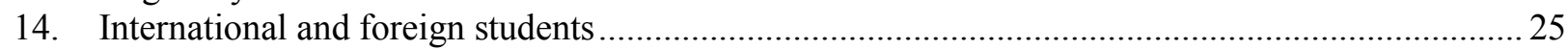

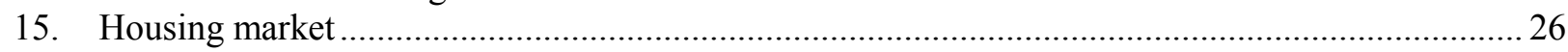

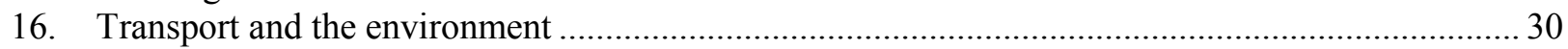

\section{Boxes}

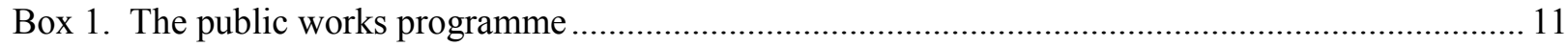

Box 2. Recent reforms in primary and secondary education............................................................ 18

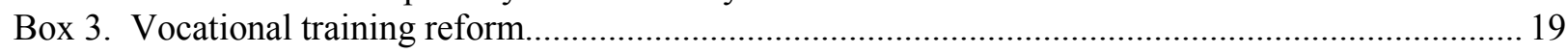

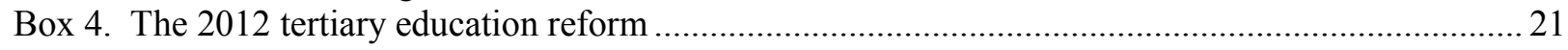

Box 5. Main recommendations to tackle labour market mismatches and promote mobility .................. 30 
ECO/WKP(2014)18

\title{
Tackling labour mismatches and promoting mobility
}

\author{
By Stéphane Sorbe ${ }^{1}$
}

\section{Substantial labour mismatches weigh on economic performance}

Labour mismatches contribute to low employment and weak productivity (Figure 1). Broadly speaking, mismatches can be defined as imbalances between labour supply and demand across geographic regions, sectors, occupations and skills. In Hungary, the main mismatch is a large structural excess of low-skilled labour supply, resulting in a very low employment rate among this group (Figure 2, Panel A; Fazekas and Scharle, 2012). In contrast, high-skilled labour is in somewhat tight supply in certain fields, such as medical professions, and more companies report skill shortages than the European Union (EU) average (European Commission, 2013a). Among employed workers, under or over-qualification appears less common than in most OECD countries (Figure 2, Panel B; OECD and Statistics Canada, 2011; Randstad, 2012; in contrast, Quintini, 2011, suggests frequent under-qualification of workers), but many people occupy a position not directly related to their field of study, a common pattern across Eastern European countries (Figure 2, Panel C). Mobility of workers is essential to good matching. Although jobto-job mobility is about average, the reallocation of labour across economic sectors has slowed since the mid-1990s (Harasztosi, 2011) and geographic mobility is low, resulting in persistently large regional discrepancies in the unemployment rate (Figure 3).

Figure 1. Employment and labour productivity growth have been low Per cent
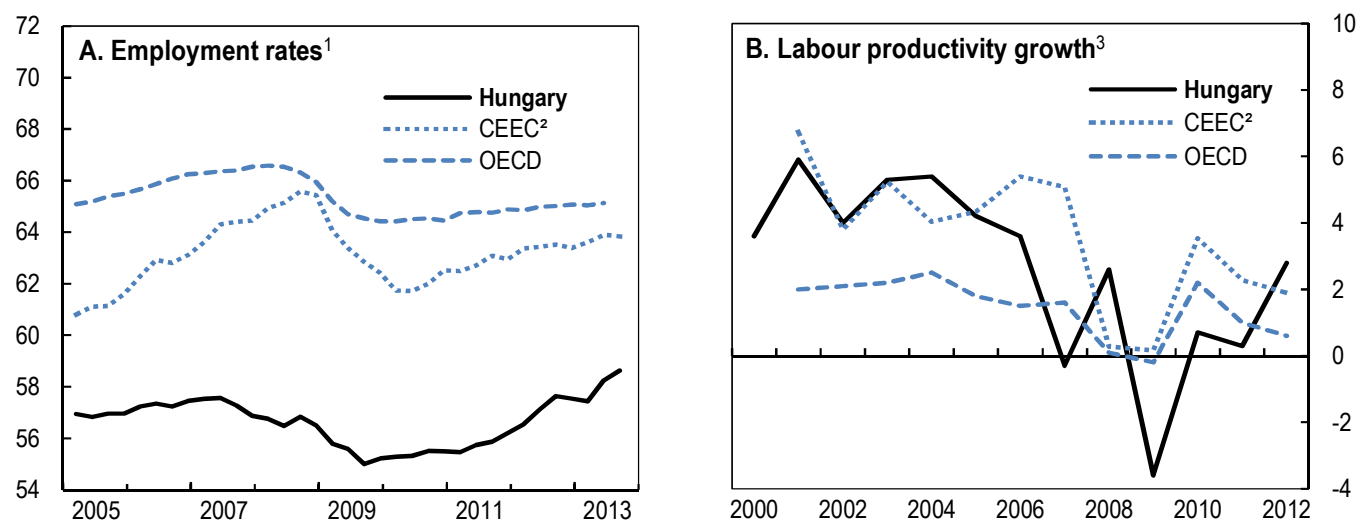

1. Age 15-64

2. Unweighted average of other Central and Eastern European countries (Czech Republic, Estonia, Poland, Slovak Republic and Slovenia).

3. GDP in constant prices per hour worked, total economy.

Source: OECD (2013), OECD Main Economic Indicators and OECD Productivity Statistics (databases), December.

1. This paper originally appeared as chapter 2 in the OECD Economic Survey of Hungary 2014, published in January 2014 under the authority of the Economic and Development Review Committee. Stéphane Sorbe is an economist in the OECD Economics Department. The author is grateful Yuri Belfali, Pierre Beynet, Andrew Dean, Robert Ford, Gábor Horváth, Mark Keese, Balint Menyhert and Álvaro Pina for valuable comments and suggestions on earlier drafts as well as for discussions with Hungarian government officials and independent experts. Special thanks go to Desney Erb for statistical assistance and Sylvie Ricordeau for editorial assistance. 

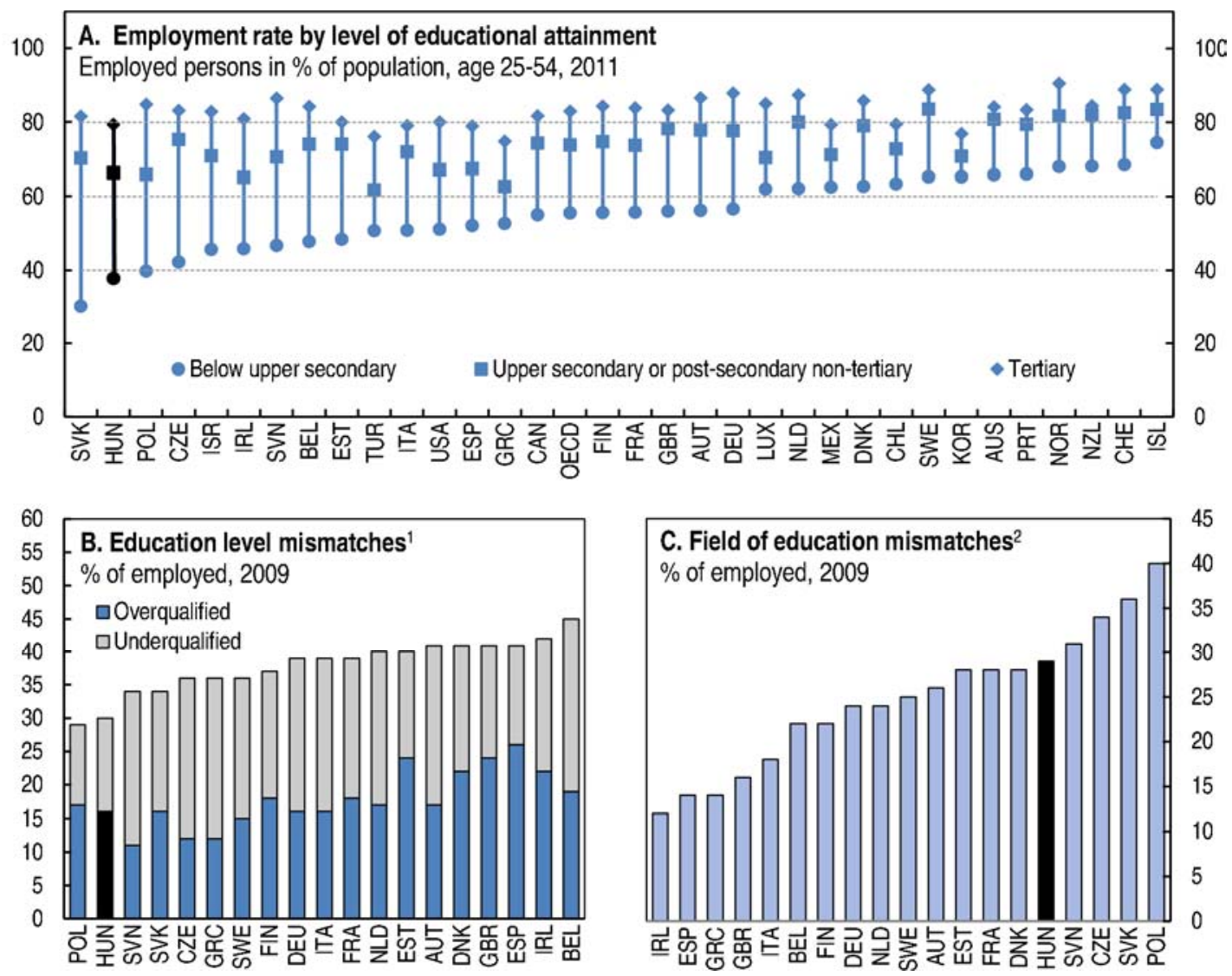

1. To assess education level mismatches, jobs and qualification levels were classified using the International Standard Classification of Occupation (ISCO) developed by the International Labour Organisation (ILO).

2. Field of education mismatches take place when the level of education matches job requirements but the type of education (e.g. field of study) is inappropriate for the current job

Source: OECD (2013), Education at a Glance 2013: OECD Indicators and Randstat (2012), "Into the Gap: Exploring Skills and Mismatches", SEO Report, No. 2011-56, SEO Economic Research.

Certain labour mismatches originate in the 1990s transition to a market economy. As the sectoral composition of the economy changed rapidly and workers moved from state-guaranteed employment to the open labour market, an important group of workers with low or ill-adapted skills could not find jobs. However, mismatches have apparently worsened over the past decade, as illustrated by rising long-term unemployment and an outward shift in the Beveridge curve (Figure 4). This reflects limited progress made in reintegrating these workers and, more worryingly, that the skills of younger generations exiting the education system have been poorly matching labour market needs. Indeed, youth unemployment is high and only partly cyclical. Looking ahead, two factors may aggravate labour mismatches. First, technological progress tends to reduce demand for low to medium-skilled labour and increase demand for high-skilled labour. Second, young high-skilled emigration appears to have increased over recent years, although from a relatively low base. 
Figure 3. Evolution of the unemployment rate by county

Registered jobseekers in per cent of economically active population aged 15-64 in $2012^{1}$

1. Data for 2004 is shown in parentheses for comparison.

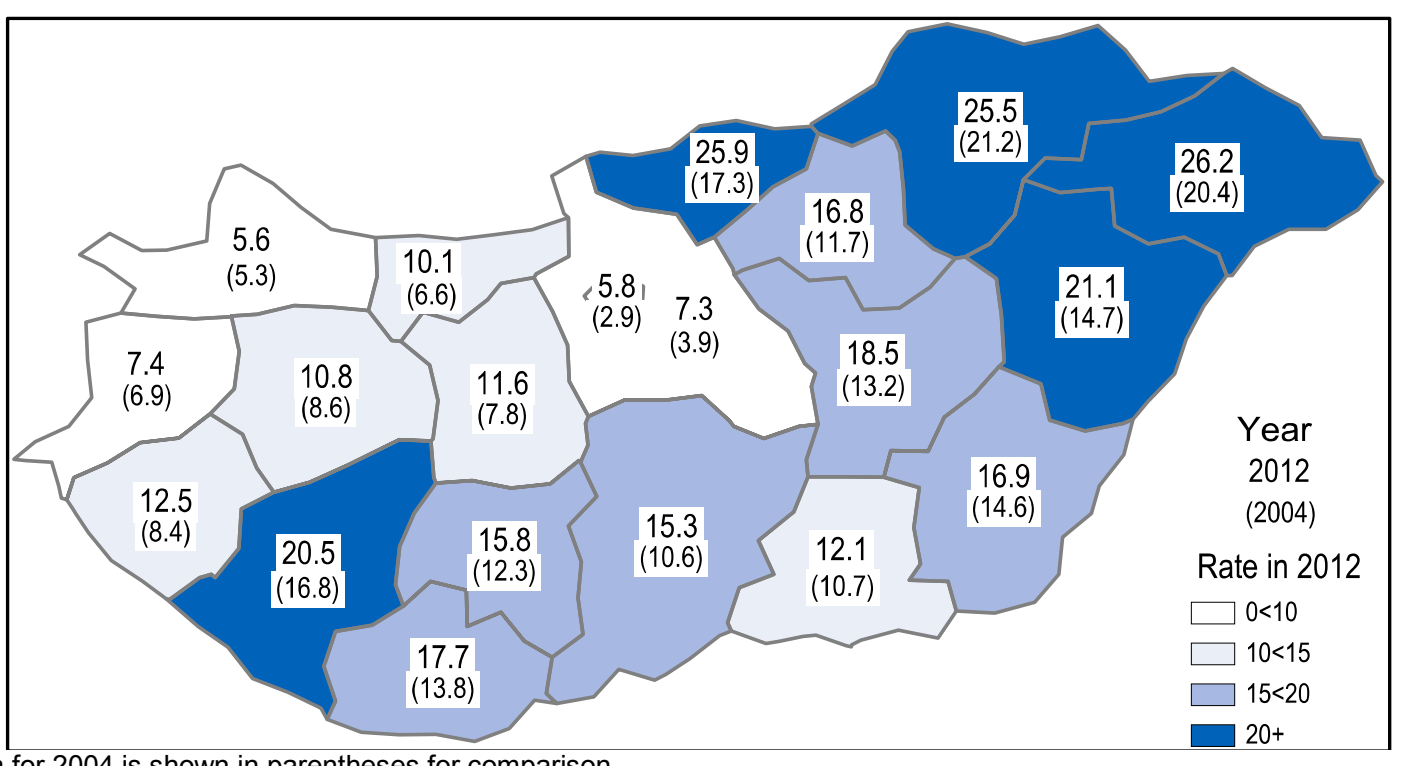

Source: HCSO (2013), "Regional Statistics: Labour Market”, STADAT Tables, Hungarian Central Statistical Office, December.

Figure 4. Unemployment and job vacancy rates

Per cent
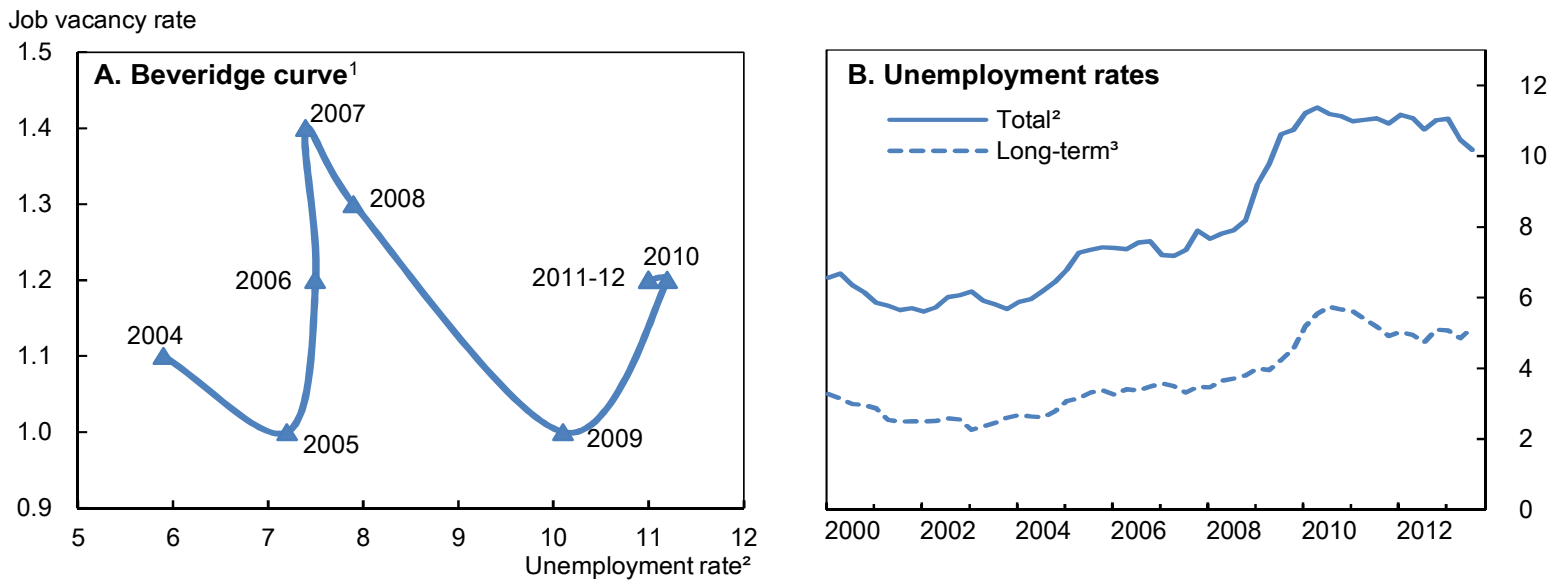

1. Break in series in 2009 due to a change in industry classification.

2. $\quad$ Age $15-64$

3. Long-term covers unemployment duration of twelve months or over.

Source: Eurostat (2013), "Labour Market", Eurostat Database, December and OECD (2013), OECD Main Economic Indicators (database), December.

Tackling labour mismatches could yield large benefits in terms of employment and productivity by improving the allocation of labour resources. In the short term, lower labour costs would foster demand for low-skilled labour. In the longer term, labour supply should be upgraded by raising education outcomes and ameliorating the school-to-work transition. The mobility of workers across occupations and sectors is supported by the relatively low employment protection legislation (EPL) and the decentralised wage negotiation settings, but should be further propped up by enhanced activation policies and more focus on 
lifelong learning. To address geographic mismatches, the authorities have recently taken limited steps to encourage jobs moving to job-poor areas (through the creation of low-tax zones) and workers moving to job-rich areas (through relocation subsidies), but broader reforms of housing and transport are needed to reduce relocation and commuting costs.

\section{Enhancing demand for low-skilled labour}

Less than $40 \%$ of people with at most lower-secondary education are in employment (Figure 2). A number of them are employed in the public works programme with limited prospects of regular employment. This reflects both a lack of skills and employability, as some workers have been out of employment for a long time, and the relatively high cost of low-skilled labour. The main reason is a high tax wedge on low salaries. The minimum wage, by contrast, is only slightly above the OECD average relative to the median wage (Figures 5 and 6).

Figure 5. Average tax wedge on low to average wages ${ }^{1}$

Per cent of labour costs
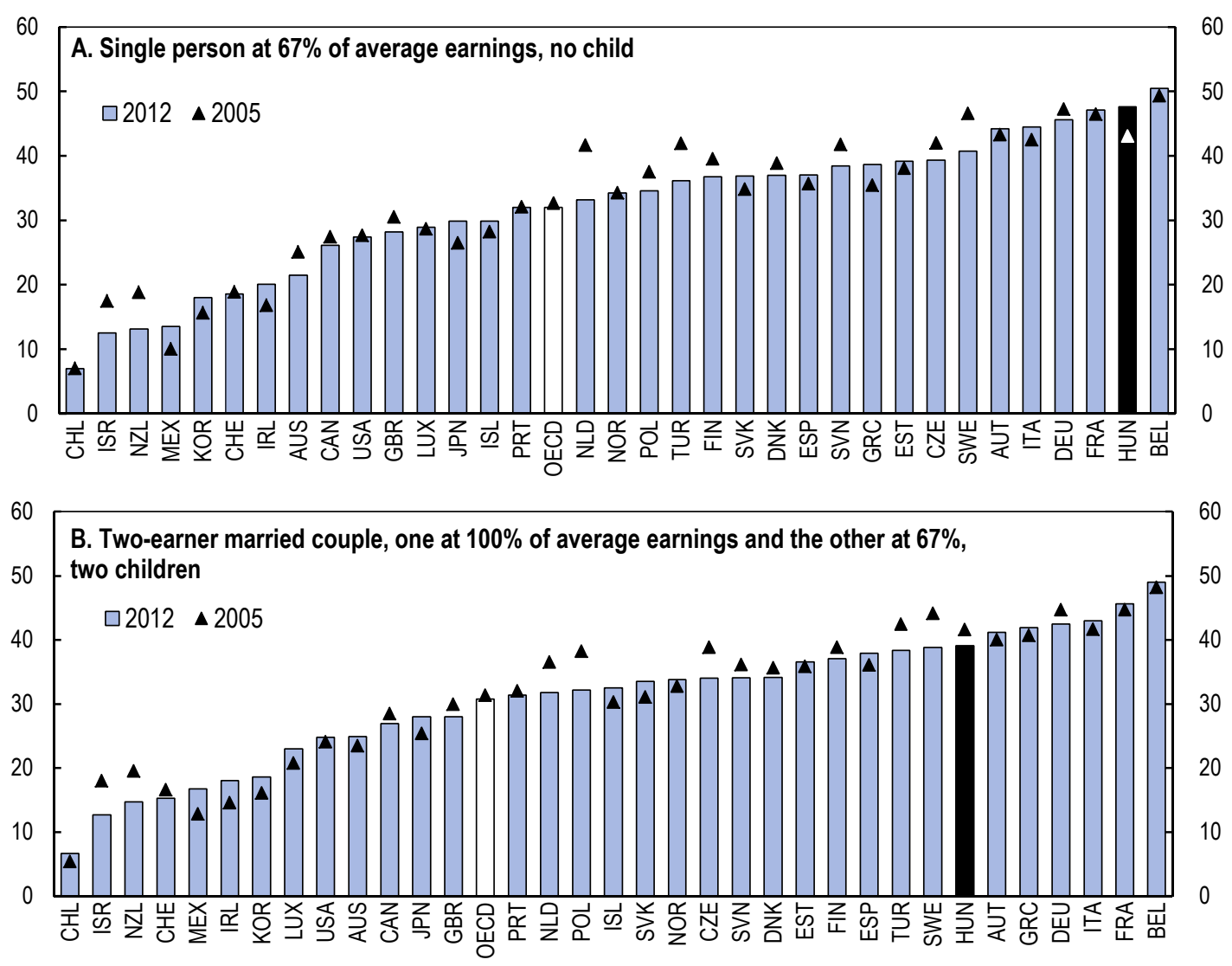

1. Taxes are the sum of personal income tax and employee plus employer social security contributions together with any payroll tax less cash transfers.

Source: OECD (2013), “Taxing Wages: Comparative tables”, OECD Tax Statistics (database), December. 
Figure 6. Minimum wage

Gross minimum wage as a per cent of median wages of a full-time worker

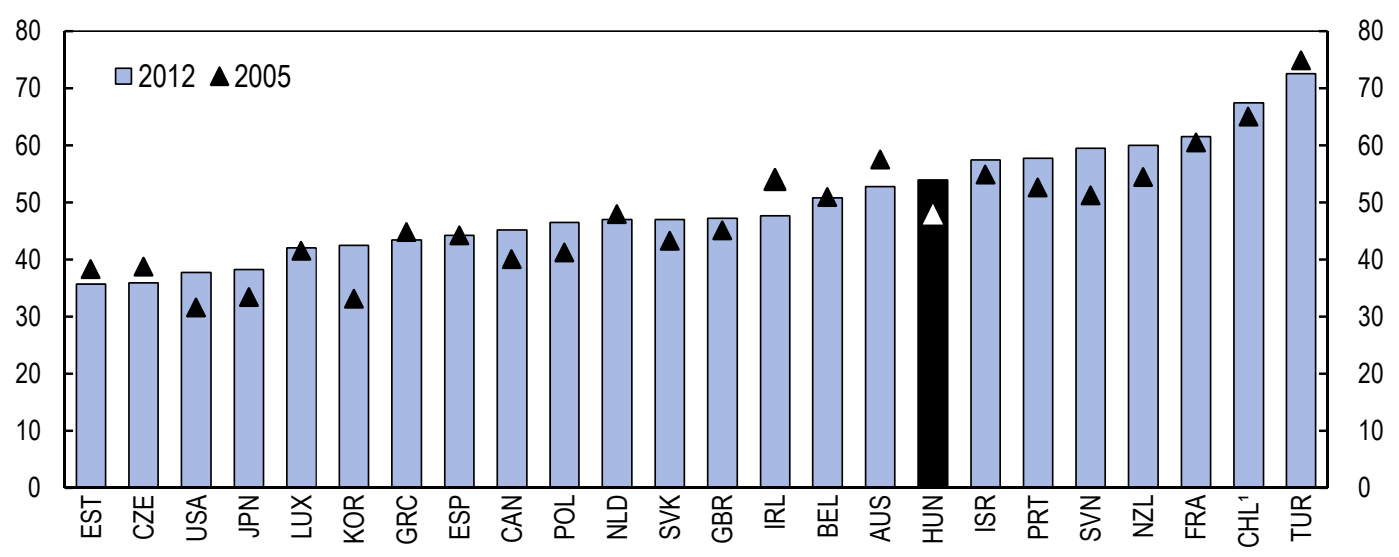

1. Data for 2011 and 2006.

Source: OECD (2013), OECD Employment and Labour Market Statistics (database), December.

\section{Reducing the tax wedge on low salaries}

The tax wedge on low salaries reflects high social security contributions and the $16 \%$ flat income tax rate (Ladányi and Kierzenkowski, 2012). The flat tax applies from the first forint of income and there is no deduction for employment since the abolition of the employment tax credit in 2012. In 2013, the Job Protection Act reduced the tax wedge for certain groups. On the first HUF 100000 of wages (about the level of the minimum wage), the rate of employer social security contributions was lowered from $28.5 \%$ to $14 \%$ for younger (below age 25), older (above age 55) and unskilled (i.e. occupying a position requiring no qualification) workers. In addition, it was lowered to zero for two years for young career starters, long-term unemployed and returning mothers. This second component replaced the Start programme, which used to offer support for one year, but on wage costs up to $150 \%$ of the minimum wage.

The Job Protection Act was a step in the right direction of reducing the tax wedge on low salaries, which nevertheless remains substantially higher than the OECD average. A micro-simulation exercise suggests that the programme could boost employment by about 1\% (Benedek et al., 2013a). However, cuts in social contributions could have been better targeted, as many high income earners benefit $-14 \%$ of the target group earns more than the average wage - while some low-wage middle-aged workers do not. To improve targeting, the cuts should be phased out above a certain wage level (progressively to avoid spikes in marginal tax rates), such as at the average wage. The proceeds could serve to further reduce the tax wedge on low salaries, for example by contributing to the costs of introducing an employment tax credit that progressively declines with the wage level.

\section{Avoiding excessive minimum wage increases}

The minimum wage is set by the government after consultation of the social partners within the National Economic and Social Council. Since 2000, the minimum wage was increased faster than the average wage and labour productivity (Figure 7). In 2012, it was raised by $19 \%$ in order to counter the negative effect of higher taxes on the purchasing power of recipients. It was raised by another $5 \%$ in 2013 , which turned out to be higher than inflation, and by $3.6 \%$ in 2014 . Rapid increases in the minimum wage have supported the income of the employed low-skilled, but they have also led, at least in the early 2000s, to important job losses, especially in small companies and disadvantaged areas (Kertesi and Köllö, 2003). Now that the minimum wage is slightly above the OECD average relative to the median wage (Figure 6), 
the authorities should refrain from increasing it more than suggested by inflation and productivity developments, and consider even freezing it for some time. Introducing a formula-based benchmark for minimum wage increases, as a way to inform decisions by the authorities, could help in this respect.

Figure 7. Compensation and productivity ${ }^{1}$

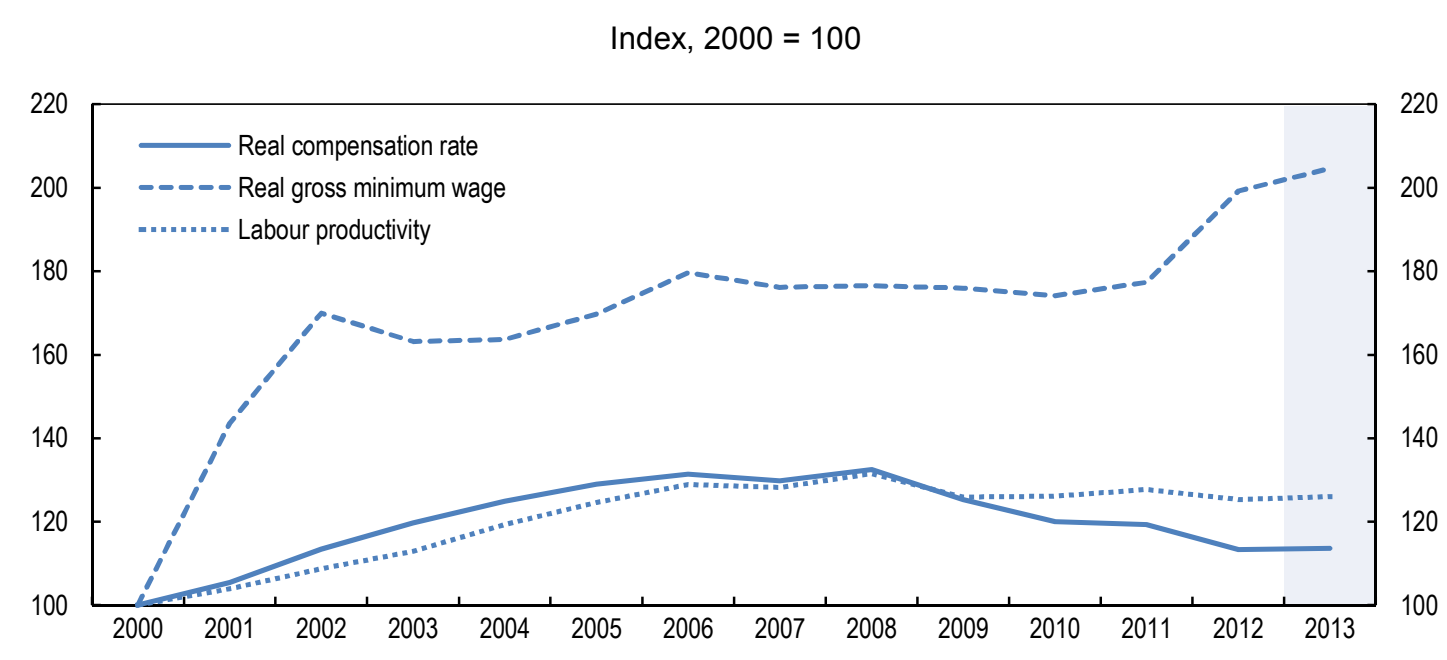

1. Real compensation rate and labour productivity of the total economy. Projections for 2013.

Source: OECD (2013), OECD Economic Outlook: Statistics and Projections (database), December.

The authorities should consider moving progressively towards a lower minimum wage in disadvantaged regions, where the oversupply of low-skilled workers is more acute. The 2011 reform of the labour code offers this possibility. According to Scharle and Váradi (2009), a 30\% decrease in the minimum wage in well targeted sub-regions could boost unskilled employment rate by $6-12 \%$ within two or three years. The potential impact on income inequalities is ambiguous, as lower wages would increase inequalities but higher employment would reduce them.

In the current context of high youth unemployment, a lower minimum wage for the youth could also be envisaged, as a way to facilitate the school-to-work transition. Youth minimum wages are in place in eight OECD countries, such as the Netherlands, and have been found in some cases to have a positive, albeit small, effect on employment (OECD, 2010a). In the case of Hungary however, these benefits should be balanced against the associated risks in terms of increased tax evasion through wage underreporting and of segmenting the labour market by generalising low-paid jobs among the youth.

The minimum wage debate is closely related to tax evasion issues, as wage underreporting remains widespread. The average rate of wage underreporting is estimated to be at least 9-13\%, with higher rates in the lowest and highest income groups (Benedek et al., 2013b). Wage underreporting generates substantial fiscal losses, poses fairness issues and tends to be regressive. To mitigate the issue, a $17 \%$ higher minimum wage is applied to jobs requiring at least secondary school or vocational education, but this is not ideal because of the potential adverse effects on employment. Reinforcing direct measures against tax evasion would be preferable. Sanctions for wage underreporting range between $50 \%$ and $200 \%$ of the unpaid tax (depending on whether tax evasion is judged deliberate), but the probability of being caught is not sufficient to deter underreporting. Enhancing this probability requires strengthening qualitatively the capacity of the tax administration, better using the information available to target individuals and companies for tax inspections, and putting in place a strong framework to prevent corruption of tax officials. Regarding the latter, recent initiatives to reinforce whistle-blower protection go in the right direction. 


\section{Enhanced activation policies and lifelong learning}

In combination with lower labour costs, enhanced activation policies are needed to enable low-skilled workers to find a suitable job, possibly after training. In recent years, more resources have been directed to the public works programme and EU-cofinanced active labour market programmes for vulnerable groups have been scaled up. At the same time, the duration of unemployment benefits has been drastically shortened and the administrative capacity of the Public Employment Service (PES) reduced. The ability of public works to promote reintegration to the regular labour market remains very low (Box 1).

\section{Box 1. The public works programme}

Public works programmes have been in place under different forms since the early 2000s and have been massively scaled up since 2009 (Figure 8). They typically consist of low value-added jobs in sectors like agriculture or road maintenance. Employment can be either full or part-time and, in 2012, lasted on average eight months. The programme is organised by the Ministry of Interior and participants are mostly employed by municipalities and government-owned companies, although their wages are paid by the central government. Participation is compulsory in the sense that refusing a suitable offer to participate renders one ineligible for unemployment benefits and social assistance. The salary for full-time employment is about three quarters of the minimum wage and three times the level of social assistance. Most participants have low to very low skills - about half of participants have not gone beyond primary school - and largely come from the Roma minority.

Figure 8. Participation in public works programmes

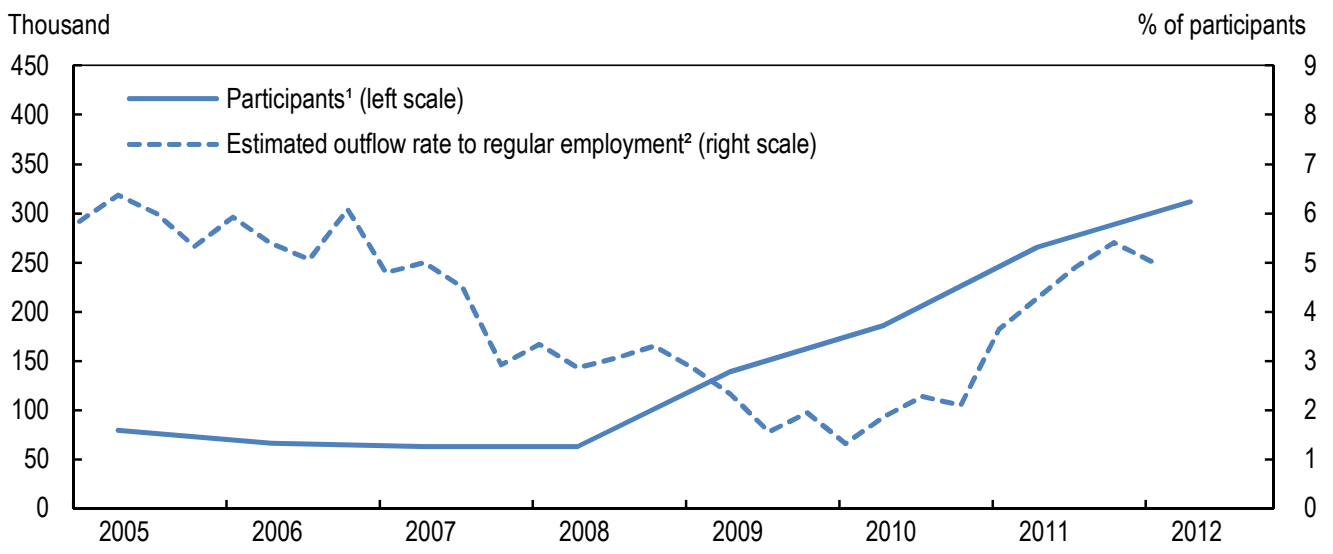

1. Number of individuals having participated in public works, even for a short time, during the year.

2. Share of public works participants that find non-fostered employment in the following quarter. Calculations by Cseres-Gergely et al. (2013) are based on micro data from the Labour Force Survey. Fostered work includes public works but also other kinds of publicly supported jobs

Source: NFSZ, A foglalkoztatáspolitikai eszközök müködése, Nemzeti Foglalkoztatási Szolgálat (National Employment Service), various editions and Z. Cseres-Gergely, G. Kátay and B. Szörfi (2013), "The Hungarian Labour Market in 2011-2012", in K. Fazekas et al. (eds) (2013), The Hungarian Labour Market, 2013, Centre for Economic and Regional Studies, Hungarian Academy of Sciences and National Employment Non-Profit Public Company Ltd.

Reintegration of participants to regular employment appears to have increased since 2009, but remains very low, especially in municipality-organised programmes. In 2012, the share of public workers finding a regular job just after public works was only $5 \%$ (Figure 8 ), although the rate after half a year was $9 \%$.

\section{Reintegrating public works programme participants}

Public employment programmes are generally considered to be among the least effective activation instruments (Card et al., 2010). Past experience in Hungary has been no exception (Budapest Institute, 2011). Thus, public works should remain a transitional instrument, as envisaged by the authorities. They should only be targeted to low-skilled people who have been out of work for a long period of time. For 
other groups, traditional activation procedures via the PES - generally among the most efficient activation instruments internationally - are likely to be more efficient, provided there is sufficient PES capacity (see below). Given their low skills, lack of recent work experience and the potential discrimination against the Roma, activating public works programme participants is very difficult and requires a determined and broad-based approach, combining training and support in the transition to the regular labour market.

Following a recommendation of the 2012 OECD Economic Survey of Hungary (OECD, 2012a), the authorities intend to put more focus on training public works participants. The share of participants receiving training was only about $5 \%$ in 2012 . The authorities aim to use EU funds to train $30 \%$ of the participants in the winter 2014 programme that started in November 2013. Training focuses on agricultural and basic general and professional skills. Given the large uncertainty about which training programmes may work for which groups of participants, the efficiency of the different programmes should be carefully monitored to improve quality and targeting over time. More focus on services could also be considered, as they may offer more employment perspectives than agriculture in the long term. Training will be organised exclusively by the public Türr István Institute in charge of adult vocational training. This centralisation may facilitate organisation, but there is a risk of duplication of roles and lack of coordination with the PES, which already provides activation for the unemployed, notably by subcontracting training to a network of (mostly private) providers. Greater coordination and integration between the two would make activation more effective, while involving some private providers in the training of public works participants should be considered.

In combination with training, the transition of public workers to regular jobs should be facilitated. At the local level, more coordination is needed between municipalities, job centres in the PES network, non-governmental organisations (NGOs) and private companies. For example, this could take the form of municipalities being allowed and having incentives to "lend" public workers, preferably after or in combination with training, to NGOs and private companies in a simple administrative framework (however, an existing scheme has generated almost no demand because of limited scope, administrative complexity and lack of incentives for municipalities). Although this may displace other low wage workers (but in its current form, the public works programme may already displace some), such a scheme would probably increase employment overall, displace some informal work and facilitate the reintegration of public workers. More generally, the incentives of municipalities to focus on activation should be enhanced, for example by offering them a financial bonus linked to the medium-term labour market outcome of participants.

As pilot projects have shown, empowering public works participants to create micro-enterprises could also be part of the solution. Promoting such entrepreneurship requires further reducing administrative burdens and developing specific training and mentoring as well as micro-financing.

\section{Strengthening assistance for jobseekers}

PES staffing appears low in an international perspective, although the different remit of PES across countries makes comparisons difficult (Table 1). Since the mid-2000s, the number of jobseekers per PES staff has increased by a half. A modernisation of PES infrastructures may have raised efficiency, but the earmarking of some resources for tasks such as rehabilitation for the disabled has also left fewer staff for standard activation policies. The consequence is that contacts with the unemployed are often limited to compulsory administrative checks, leaving little room for individualised assistance. To counter this, the authorities are implementing a partly EU-financed programme for 2011-15 to provide more complex assistance to disadvantaged groups, such as the young, low-skilled or disabled job seekers. This is welcome, as such personalised support may increase employment perspectives of beneficiaries (Budapest Institute, 2013). However, it should come with a broader increase in the capacity of the PES to ensure that all jobseekers receive sufficient job search assistance. In addition, further use of the available data through 
the development of a statistical profiling system would enhance the targeting and efficiency of activation. Rationalising the network of job centres could also be considered, as many local centres, although offering the benefit of proximity, are too small to provide complex assistance services (Fazekas and Scharle, 2012).

Table 1. Average caseload in the public employment service

\begin{tabular}{|c|c|c|c|c|}
\hline & Year & $\begin{array}{l}\text { Registered job } \\
\text { seekers } \\
\text { (thousand) }\end{array}$ & $\begin{array}{l}\text { Public employment } \\
\text { service (PES) staff } \\
\text { (thousand) }\end{array}$ & $\begin{array}{l}\text { Job seekers per PES } \\
\text { staff member }\end{array}$ \\
\hline \multicolumn{5}{|l|}{ In Hungary } \\
\hline & 2000 & 390.5 & 4.2 & 94 \\
\hline & 2005 & 410.6 & 4.4 & 94 \\
\hline & 2006 & 403.4 & 4.3 & 94 \\
\hline & 2007 & 445.0 & 3.9 & 113 \\
\hline & 2008 & 477.4 & 4.0 & 119 \\
\hline & 2009 & 604.6 & 4.3 & 139 \\
\hline & 2010 & 591.3 & 4.6 & 130 \\
\hline & 2011 & 552.3 & 4.3 & 129 \\
\hline & 2012 & 569.3 & $(4.2)^{2}$ & $(135)^{2}$ \\
\hline & 2013 & . & $4.2 \quad(4.4)^{2}$ & $\ldots$ \\
\hline $\begin{array}{l}\text { In European comparison }{ }^{3} \\
\text { (the remit of the PES varies across countries) }\end{array}$ & 2011 & & & \\
\hline Austria & & 258.6 & 4.9 & 53 \\
\hline Belgium & & 547.4 & 10.0 & 54 \\
\hline Czech Republic & & 509.2 & 7.3 & 70 \\
\hline Denmark & & 207.7 & 5.8 & 36 \\
\hline Estonia & & 53.2 & 0.5 & 108 \\
\hline Finland & & 470.4 & 3.9 & 120 \\
\hline Germany & & 5207.6 & 110.0 & 47 \\
\hline Greece & & 576.6 & 3.4 & 169 \\
\hline Ireland & & 444.9 & 0.6 & 778 \\
\hline Netherlands & & 625.6 & 5.0 & 125 \\
\hline Poland & & 2011.2 & 23.8 & 84 \\
\hline Portugal & & 639.7 & 3.6 & 177 \\
\hline Slovak Republic & & 401.5 & 2.3 & 172 \\
\hline Slovenia & & 110.7 & 1.0 & 112 \\
\hline Spain & & 5745.3 & 9.4 & 613 \\
\hline Sweden & & 679.0 & 10.8 & 63 \\
\hline United Kingdom & & 1473.0 & 72.9 & 20 \\
\hline
\end{tabular}

1. For Hungary, this includes persons employed within the EU programmes financed by the European Social Fund. Break in series in 2012.

2. Figures in parentheses include staff of the Hungarian Labour Inspectorate and National Institute for Vocational and Adult Training which were merged with the National Employment Office. The number for 2013 is an estimate.

3. 2010 for job seekers for Greece and United Kingdom. The PES data shows the latest data available from the country fiches of the European Commission website, 2010 or 2011 in most cases. The remit of the PES varies across countries in terms of groups covered (e.g. disabled, employed jobseekers) and services provided (e.g. career guidance, in-house training). For more details see the "PES Business Models" study by Mobility Lab available from the European Commission website (link below).

Source: For Hungary - K. Fazekas and Á. Scharle (eds.) (2012), From Pensions to Public Works: Hungarian Employment Policy from 1990 to 2010; Hungarian Central Statistical Office and National Employment Office. For other European countries - Registered job seekers from Eurostat (2013), "Labour Market Policy", Eurostat Database, September and PES staff numbers from European Commission, Employment, Social Affairs and Inclusion, Public Employment Services, http://ec.europa.eu/social/main.jsp?catld=105\&langld=en, accessed September 2013.

In complement to other instruments, a "First Job Guarantee" programme was launched in 2012 and extended in 2013 to facilitate the labour market integration of young people. In the programme, PES centres select first-time jobseekers and place them into selected companies. Their wages are fully 
government financed for six months up to $150 \%$ of the minimum wage, with since 2013 an obligation of further employment for at least three months. Of the more than 7000 participants in 2012, around half were still employed after the end of the wage subsidy. The personalised support for first-time jobseekers is welcome, although by mobilising scarce PES resources it may come at the expense of other jobseekers if the capacity of the PES is not increased. As deadweight costs of such schemes can be important, good targeting is essential, but also difficult. Higher-skilled people may not need such high wage subsidies and some lower-skilled ones may need to train first before working, or to combine the two. Extending the scheme to vocational apprenticeships could be interesting in this respect. In any case, the full government financing seems excessive as it gives job centres the power to offer free labour to selected companies (with only a short obligation for further employment). Reducing the amount of wage subsidy would mitigate this issue, while also lowering the fiscal cost of the scheme, as well as perhaps giving companies greater incentives to invest into participants.

\section{Increasing the duration of unemployment benefits}

In 2012, the duration of unemployment benefits was reduced from nine to three months for workers aged below 55 (against an OECD average of 15 months in 2010). The measure may stimulate labour supply, but could have a high cost in terms of poverty and labour misallocation, especially given the current economic slack. Indeed, it leaves little time for jobseekers to find the most suitable job and may also deter them from engaging in training or geographic mobility, hampering the reallocation of workers across sectors and regions. Empirical evidence suggests that shorter periods of benefit are associated with lower job reallocation and thus lower productivity (Boeri and Macis, 2010). Another indirect consequence is to reduce the leverage of the PES over jobseekers. After the measure, less than $10 \%$ of jobseekers still receive unemployment benefits and incentives to maintain contact with the PES have weakened. This leaves almost no scope for a system of gradual sanctions to promote active job search. Overall, the duration of unemployment benefits should be increased somewhat. Longer unemployment benefits should be accompanied by adequate monitoring and enforcement of job search requirements. Also, benefits could decline over time to further encourage active job search.

\section{Encouraging lifelong learning and enhancing its quality}

Lifelong learning can play an important role in fostering mobility across occupations and sectors, but it is poorly developed in Hungary (Figure 9; OECD, 2012b). In 2011, only 14\% of the unemployed were in training. Incentives for companies to train their staff were reduced in 2012 , as the possibility of fully deducting training costs from the vocational training contribution (a 1.5\% employer contribution on wages) was eliminated, except for apprentices. Additional EU funds have more than replaced this subsidy in 2012-13, although they may also involve more administrative costs. Reinstating a subsidy for training costs could be considered, in which case it should preferably be kept partial to reduce deadweight costs and potential misuse. The significant size of the informal economy may also hamper lifelong learning, as informal employers have less incentive to train workers.

An alternative (or complementary) approach could be to place the subsidy with individuals rather than companies, for example by creating a system of individual learning accounts. Such systems exist under different forms in a number of OECD countries, such as France, United Kingdom and United States (Cedefop, 2009; Gautié and Perez, 2012). Such a shift could support mobility, as workers would be more likely than companies to choose training which allows them to subsequently change sector. On the downside, individual learning accounts can be administratively complex and have difficulties to reach the low skilled. 
Figure 9. Adults in education and training

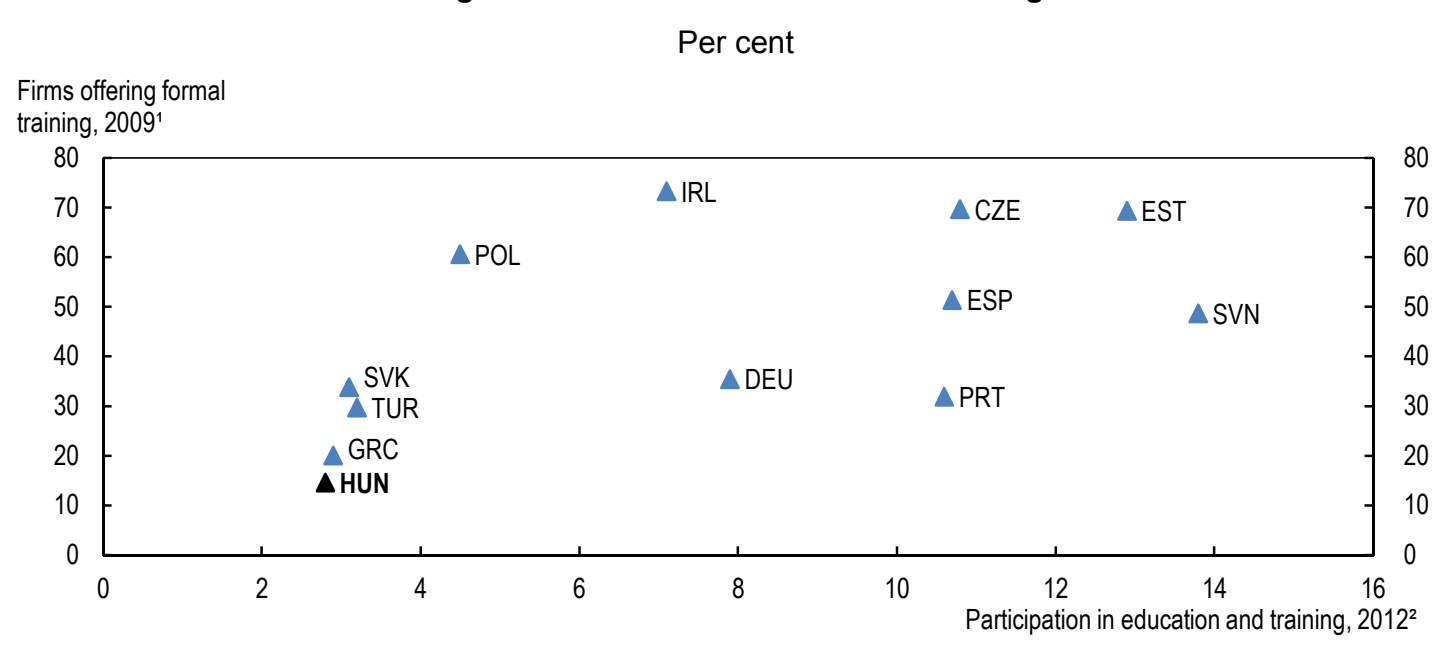

1. Firms offering formal training programmes to their permanent, full-time employees. Data for 2008 for Turkey; 2005 for Germany, Greece, Ireland, Portugal and Spain.

2. Participation in formal and non-formal education and training by 25-64 year-olds. Per cent of population in same age group.

Source: Eurostat (2013), "Population and Social Conditions: Lifelong Learning - LFS data", Eurostat Database, December and World Bank (2013), Enterprise Surveys, www.enterprisesurveys.org.

Steps are needed to improve the quality of training, especially for jobseekers. The sector is very fragmented, as local PES centres contract out training to more than 1000 private institutions and for a smaller part to the (public) Türr István Institute. Although some tools have long been in place to evaluate the efficiency of the main labour activation policies (in the form of annual monitoring by the National Employment Office and occasional reports by independent researchers), little is known about the efficiency of individual training providers. Anecdotal evidence suggests uneven quality and even some cases of corruption, and a high drop-out rate. Where evaluations are in place, generally in the form of questionnaires to participants about their labour market situation after a few months, they are of little use because of high non-response rates.

To augment the labour market relevance of training, the authorities have focused it more on vocational, language and information technology (IT) skills - in the latter two fields, already 70000 adults received EU-funded training in the year to September 2013, half of whom have completed it successfully (the programme is ongoing). More generally, enhancing efficiency requires improving the quality of evaluation, for example by giving participants a financial incentive to answer questionnaires. In a welcome step, a recent law introduced a requirement for the authorities to evaluate every other year the quality of training institutions. These evaluations should be made public and jobseekers be more involved in the choice of their training provider, as a way to push providers to compete on quality. Such increased transparency would also reveal what type of training best fits jobseekers' abilities and labour market needs, allowing more effective orientation of jobseekers.

\section{Improving initial education to match labour market needs}

In the longer term, reducing labour mismatches requires enhancing education outcomes and skills to better match labour market needs. Certain education outcomes are relatively good, especially given the relatively low spending (Figure 10). Secondary education attainment is relatively high among the younger generations and average PISA scores (Programme for international student assessment) are broadly in line with the OECD average (OECD, 2013a; OECD, 2010b). However, the number of early school leavers remains high, the quality of vocational training is low and participation in tertiary education still lags the OECD average. In addition, despite the relatively high pre-school attendance, the background of children 
influences their performance more than in most OECD countries (Figure 11). In turn, educational attainment has a strong impact on employment and wage prospects relative to other countries (Figure 2; OECD, 2012c). The government is carrying out vast reforms at all levels of the education system, which are presented in boxes below.

Figure 10. Public spending by level of education ${ }^{1}$

Per cent of GDP, $2010^{2}$

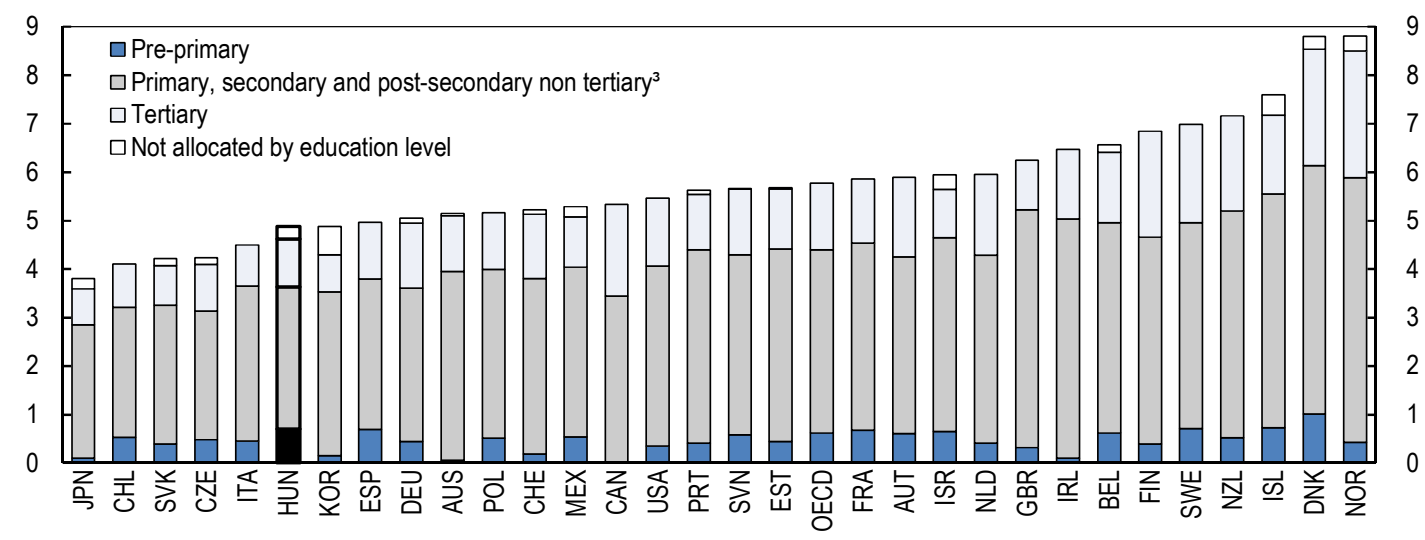

1. Direct public expenditure on educational institutions plus public subsidies to households (for living costs such as scholarships and grants to students/households and student loans) and other private entities.

2. 2009 for Canada and Germany.

3. Includes pre-primary for Canada.

Source: OECD (2013), Education at a Glance 2013: OECD Indicators.

Figure 11. Inequalities in education

Impact of socio-economic background on education outcomes, per cent, $2012^{1}$

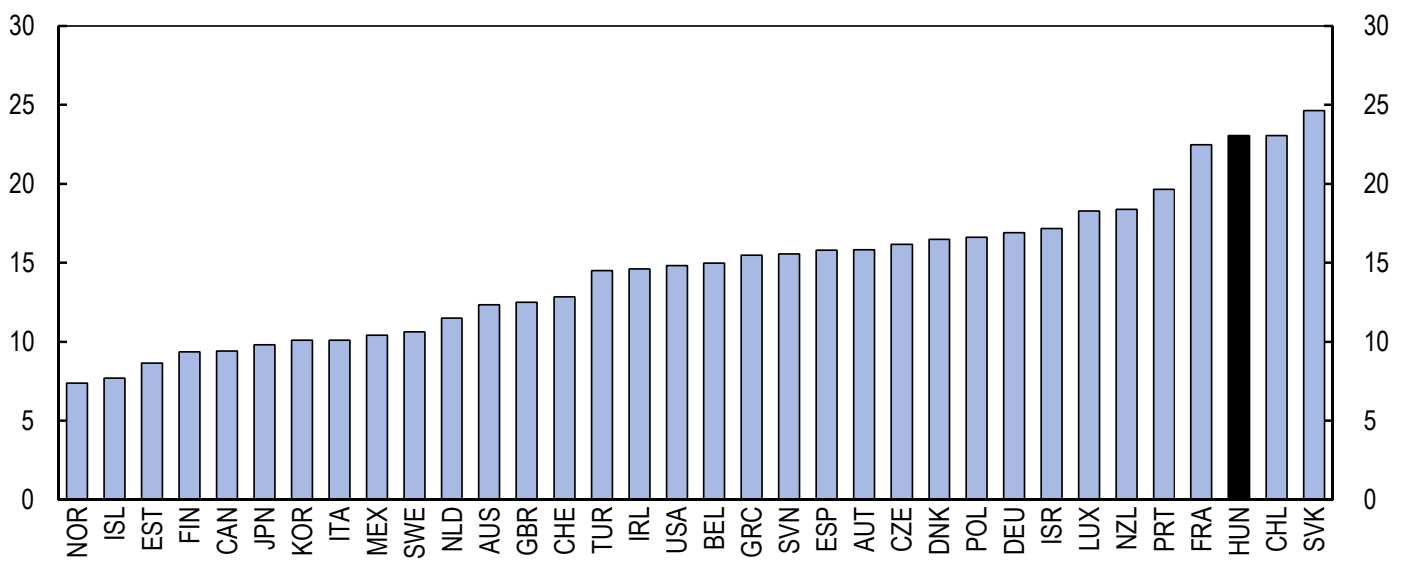

1. Percentage of variance in student performance explained by the Programme for International Student Assessment (PISA) index of economic, social and cultural status (ESCS). R-squared $x 100$.

Source: OECD (2013), PISA 2012 Results: Excellence through Equity (Volume II).

\section{Tackling inequalities in primary and secondary education}

Hungary has the highest rate in the OECD of social segregation in schools, measured on the basis of parental occupation (Jenkins et al., 2008). As a result, there are large variations in the performance of pupils across schools and only relatively low within-school variation. In particular, schools in small 
settlements (below 3000 inhabitants) have much poorer performance than others (OECD, 2010c). Segregation reflects both social inequalities across the country, including an overrepresentation of the poor and the Roma in rural areas, and the relatively widespread practice of schools to select pupils on the basis of their academic record. Selection can start at the entry to primary school and $90 \%$ of pupils are in schools which are in a position to select students (Havas, 2009; OECD, 2012d). Segregation may have increased over the past decade, as the number of schools with Roma majority among pupils has increased (European Commission, 2013b).

Reducing segregation would give better chances to disadvantaged children, as segregation is generally considered to weaken their performance. Substantial negative effects may only materialise above a certain share of disadvantaged students in the classroom (30\% to $70 \%$, depending on school characteristics), meaning that greater diversity could enhance the results of disadvantaged students without greatly affecting the results of more well-off ones (Karsten, 2010). To tackle segregation, notably of Roma children, certain schools in small rural settlements could be closed - despite political pressure to keep all schools open and their pupils sent to schools offering more socio-economic diversity in larger settlements, even though this would entail a loss of proximity and higher transport costs (which should be covered by the government to prevent school drop-out). A large scale programme to close small rural schools in Portugal in the second half of the 2000s had generally positive results in terms of efficiency and integration of disadvantaged pupils (Box 5.2 in OECD, 2013b).

Other measures could also be considered to tackle segregation, such as creating financial incentives for high-quality schools to attract disadvantaged students, or reducing to some extent the ability of schools to choose students by making it conditional on certain rules on school diversity (OECD, 2012d). A 2012 law stipulates that the ratio of disadvantaged students in each school shall not exceed the average ratio of disadvantaged people in the settlement by more than 15 percentage points. However, the effect is likely to be limited because of the existing geographic segregation.

To further improve the prospects of disadvantaged students, more resources should be targeted to schools where they are overrepresented. The 2013 recentralisation of responsibilities may help in this respect as poorer municipalities often lacked resources to finance school infrastructures, while the central government may provide more funds (Box 2). The general increase in teachers' wages may also help in recruiting and retaining more highly qualified teachers. Still, more should be done to attract the most qualified and experienced teachers and school directors to the most difficult schools, which is a key to enhancing performance (OECD, 2012d). Teachers in disadvantaged areas receive a bonus, but it only amounts to about $10 \%$ of the wage and is relatively less for more experienced teachers. To attract and retain better teachers in difficult areas, this bonus should be increased and, more generally, working conditions should be improved, including through further use of EU funds for education projects. In addition, novice teachers in disadvantaged areas should be better prepared for the specificities of their environment through specific training and mentoring. Parental engagement should also be fostered, for example by establishing home-school liaison coordinators to facilitate contacts between teachers, families and communities (OECD, 2010d).

Preserving an adequate level of school autonomy is important to allow schools to adapt to the local context, especially in disadvantaged areas. Empirical evidence suggests that decentralised education systems tend to perform better if autonomy comes with accountability (OECD, 2010e; Blöchliger et al., 2013). School autonomy was traditionally high in Hungary, but the 2013 centralising reform substantially reduced it, at least in theory. In practice, a lot will depend on how the reform is implemented and how relationships evolve between schools and the newly created Klebelsberg Institute that will manage the recentralised responsibilities for the central government. In this context, the authorities should ensure that organisational and some pedagogical autonomy remains with schools, including the management of human resources, and focus the Klebelsberg Institute on benchmarking school performance to enhance 
accountability of school directors, providing logistical support and taking initiatives to support disadvantaged students.

\section{Box 2. Recent reforms in primary and secondary education}

In 2013 , the responsibility for primary and secondary education was transferred from municipalities to the central government. Only school maintenance in larger municipalities (over 3000 inhabitants) remains a municipal responsibility. The central government took over the financing of schools, which no longer have independent budgets, as well as certain responsibilities that were traditionally devoted to school directors, such as hiring and firing teachers. To manage these new responsibilities, a new administrative layer, the Klebelsberg Institute, was created, with a network of around 200 local branches.

Teachers' wages in primary and secondary education were increased by an average 34\% in September 2013. Further increases of about $10 \%$ per year are envisaged for the three coming years. In exchange, teachers' low working time is to be increased. The measure, which follows a recommendation in the 2010 Survey, ${ }^{*}$ should help the recruitment and retention of better teachers as, after many years of wage freezes, teachers' wages had become very low vis-à-vis other occupations at the same qualification level.

A number of largely EU-financed measures aim to increase the chances of disadvantaged students. Preschool will be made compulsory for children over three years-old in 2015 ( $94 \%$ are already attending), which is a positive step given that enrolment generally enhances education outcomes of children with poor backgrounds. A socalled Sure Start programme aims to support young children in disadvantaged areas by providing pedagogic and social support in dedicated centres and promoting parental involvement. To reduce school dropout, Bridge programmes were launched in 2013 to help pupils performing poorly in elementary education to acquire basic skills and a partial vocational qualification, and an after-school support programme (TANODA) was launched. A "For the Road" programme provides support to disadvantaged pupils (at least half of them Roma) from 7th grade to the first year of university, in the form of a monthly scholarship (of an amount depending on academic results) and mentoring.

* OECD (2010), OECD Economic Surveys: Hungary 2010,

\section{Making the best of vocational training reform}

Enhancing the quality of vocational education and training (VET) is essential to improve employment prospects of the lower skilled. The quality and image of VET have gradually deteriorated after the transition to a market economy, as it failed to adapt to large changes in labour demand (OECD, 2008a; OECD, 2010f; European Commission, 2011). An important reform took effect in 2013, which aims to bring students' skills closer to labour market needs by increasing the practical component of training and involving private companies more (Box 3 ). The latter is positive as it may facilitate skills matching and the transition from school to work. To enhance effectiveness, it should be ensured that, as intended, the additional practical training takes place in companies (e.g. in the form of apprenticeships) rather than in school-based workshops or in the network of regional training centres (TISZKs) developed in the late 2000s, which have had mixed performance (Cseres-Gergely, 2010). This may require additional incentives for companies to train apprentices.

The downside of the reform is a strong risk that the shorter curriculum and the lower share of general classes will reduce general skills. A lack of general skills, in particular literacy and numeracy, can be an issue for employability in the longer term as it makes it more difficult to retrain to adapt to changing labour market needs. Delaying the tracking of students would contribute to tackle this lack of general skills. Tracking into general, vocational secondary and vocational training schools (the latter giving the most emphasis to practical skills and regrouping a quarter of students, Figure 12) currently takes place at age 14, as against 15-16 in most OECD countries. In general, early tracking is considered to have a negative impact on students assigned to lower tracks without raising average performance (OECD, 2012d). In Hungary, it also contributes to perpetuating the high existing socio-economic inequalities (Csapó 2009; 
OECD, 2010f). In addition to delaying tracking, its negative consequences should be mitigated in the shorter term by increasing opportunities to change tracks and putting in place flexible settings where children are grouped by ability only for certain subjects. This would be greatly facilitated by further merging vocational secondary schools and vocational training schools, most of which now operate under the same management but not always in the same premises. In addition, more resources should be devoted to enhancing the quality of general teaching in vocational training schools, which is generally low (Liskó, 2009).

\section{Box 3. Vocational training reform}

An important reform of vocational education and training (VET) entered into force in 2013. The curriculum in vocational training schools was shortened from four to three years and the focus on practical training increased, both in vocational training schools and in (less practical) vocational secondary schools. On average, the share of practical training should reach about $70 \%$ in vocational training schools, from about $50 \%$ before the reform. Practical training will also start earlier, in the first year of vocational school (9th grade), instead of respectively 10th grade in vocational training schools and 12th-13th grade in vocational secondary schools.

The reform also increases involvement of private companies in VET. It gives a bigger role to chambers of commerce to influence the content of training with the aim to better attune it to labour market needs. It also aims to expand the elements of dual training (apprenticeship systems), notably through additional EU financing. New professional and examination requirements aim to follow labour market needs more closely. To promote studies in potential skill shortage areas, vocational students in lists of "shortage occupations" (defined at the county level on the basis of job vacancies and surveys among companies) can be offered scholarship grants.

Figure 12. Students in secondary education

Per cent of students in full-time education ${ }^{1}$

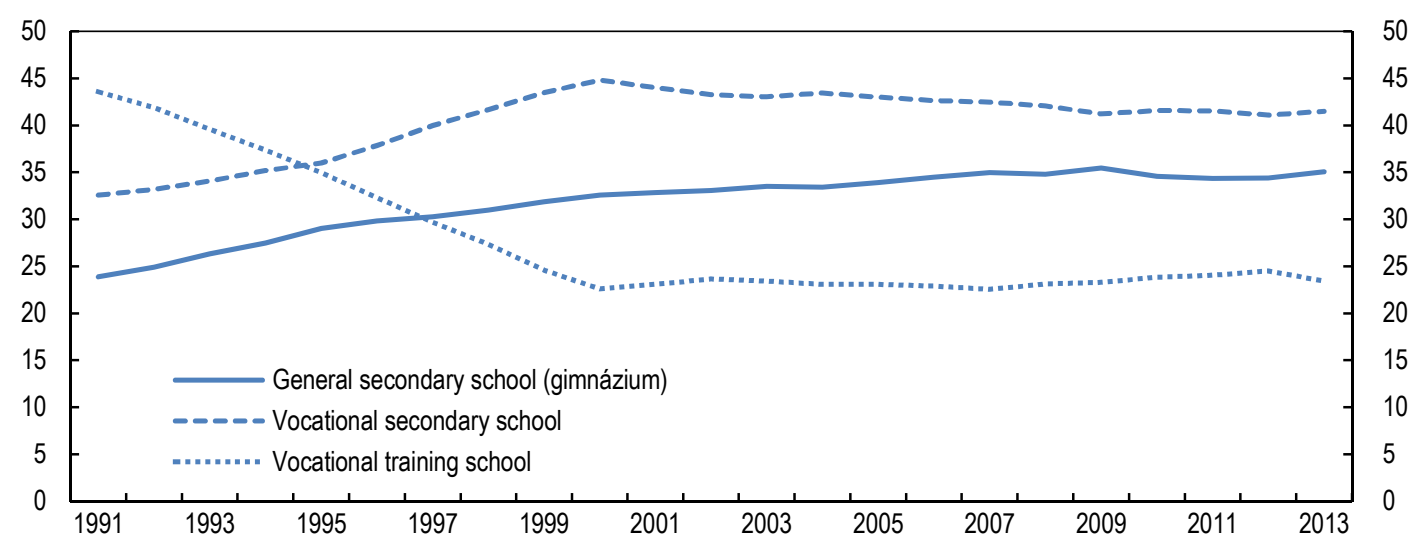

1. Vocational training school is more practical than vocational secondary school.

Source: HCSO (2013), "Education”, STADAT Tables, Hungarian Central Statistical Office, December.

The greater involvement of the private sector in defining the content of VET is welcome. To further improve the matching of training to labour market needs, a bigger role should be given to evaluation. Labour market outcomes of VET students should be collected and published on a school and programme basis, as recommended in OECD (2008a). This would enable more informed student choices, especially if it were combined with more systematic career guidance. It would also contribute to defining the so-called "shortage occupations", for which vocational students are entitled to special grants, in a more transparent 
and evidence-based manner. More generally, given the traditionally strong links between VET and manufacturing industry, the authorities should ensure that the interests of the service sector are also fully taken into account, as this sector may offer better long-term employment prospects.

\section{Enhancing participation in tertiary education and its quality}

After rising rapidly up to the mid-2000s, participation in the (mostly public) tertiary education has declined somewhat. Compounded by a high drop-out rate, this results in graduation rates still lagging the OECD average (European Commission, 2012; OECD, 2013a). Labour market prospects of graduates are rather good as they generally find a job rapidly and enjoy a relatively high wage premium (Strauss and de la Maisonneuve, 2007). Nevertheless, the quality of higher education is uneven, reflecting inter alia declining spending per student over the past decades, and outcomes may not always match labour market needs. Companies frequently complain about a lack of new engineers (GVI, 2012), although the wages of white-collar workers in industry have not over performed relative to other sectors in recent years, thus giving no clear indication of a shortage. The two-tier system, where a majority of students (state financed) - selected mainly on the basis of high-school results - pay no tuition fees, while the others (self-financed) pay some, tends to be regressive, despite an element of positive discrimination in the admissions procedure. Indeed, most students benefitting from state financing have a relatively privileged background and the self-financing option may be less accessible to disadvantaged students, who are more sensitive to financing costs and the risks associated with student loans (Semjén, 2013).

The number of applicants to tertiary education has declined by around 30\% over 2011-13 and the number of admitted students by more than $25 \%$, in contrast with the stated aim to promote participation (Government of the Republic of Hungary, 2013). This reflected to some extent demographic factors, but also much lower quotas of state financed positions in 2012 and uncertainty around the important reforms taking effect in 2013 (Table 2; Box 4). A new obligation for students to reimburse half of the state financing if studies are not completed within a reasonable time has also discouraged applications, although it may reduce drop-out rates. The authorities plan to tighten minimum admission criteria over the two coming years, which may further reduce student numbers, but again also reduce drop-out rates.

Table 2. Applications and admissions to tertiary education

General admission procedure, thousand persons ${ }^{1}$

\begin{tabular}{|c|c|c|c|c|c|c|c|c|c|c|}
\hline & & 2001 & 2004 & 2007 & 2008 & 2009 & 2010 & 2011 & 2012 & 2013 \\
\hline \multirow[t]{5}{*}{ Total } & Number of applicants & 148.9 & 167.4 & 108.9 & 97.0 & 127.3 & 140.3 & 141.0 & 110.6 & 95.4 \\
\hline & Number admitted & 98.0 & 109.9 & 81.6 & 81.1 & 94.7 & 98.2 & 98.2 & 80.1 & 72.7 \\
\hline & State financed & 50.8 & 59.9 & 48.8 & 52.8 & 65.7 & 68.6 & 67.0 & 51.3 & 54.2 \\
\hline & Self-financed & 47.2 & 50.0 & 32.8 & 28.3 & 29.0 & 29.6 & 31.2 & 28.8 & 18.5 \\
\hline & Share of state financed $(\%)$ & 51.8 & 54.5 & 59.8 & 65.1 & 69.4 & 69.9 & 68.2 & 64.0 & 74.6 \\
\hline \multirow{2}{*}{$\begin{array}{l}16 \text { subjects in law, } \\
\text { economics, social } \\
\text { sciences and humanities }\end{array}$} & Number admitted & . & . & 25.2 & 25.0 & 25.2 & 23.1 & 22.4 & 16.3 & 13.5 \\
\hline & Share of state financed (\%) & . & & 36.3 & 39.7 & 39.0 & 37.9 & 33.0 & 6.3 & 8.2 \\
\hline \multirow[t]{2}{*}{ Other subjects } & Number admitted & . & & 56.4 & 56.1 & 69.5 & 75.1 & 75.8 & 63.8 & 59.2 \\
\hline & Share of state financed $(\%)$ & . & & 70.3 & 76.4 & 80.4 & 79.7 & 78.6 & 78.3 & 89.7 \\
\hline
\end{tabular}

1. From 2007 onwards numbers include students applying and admitted to master programmes in the Bologna system, which were developed gradually. From less than 1000 in 2007, the number of applicants to master programmes rose to about 24000 in 2010, of which about 16000 were admitted.

Source: Hungarian authorities, www.felvi.hu. 


\section{Box 4. The 2012 tertiary education reform}

The reform modified the distribution of state-financed (no tuition fees) positions across institutions, introduced new contractual obligations for state-financed students, created new loans to support self-financed students, streamlined the financing of institutions and changed their governance.

The cornerstone of the admission procedure remains a ranking of applicants on a 500 point scale, reflecting mainly their previous academic results, with a 40 point bonus for applicants from disadvantaged backgrounds. This ranking determines access to university and awarding of state-financed positions. Until 2013, the government defined the number of state-financed positions by setting quotas per field of study and university. With the aim to improve the matching of students and universities, these quotas have been replaced by minimum score requirements per study programmes and capacity constraints at the level of universities. In 16 study programmes in law, economics, social sciences and humanities, score requirements to receive state financing were set much higher (between 410 and 465 points) than in the other fields (240 points, to be raised by 20 points in 2014 and again in 2015), confirming the 2012 decision to toughen drastically state-financed access to these programmes (Table 2 ).

If their studies are not completed within 1.5 times the normal length, students will have to reimburse half of the state financing received. Another new requirement for state financed students is to work in Hungary for a time period equal to the length of their study within 20 years of their graduation or to reimburse tuition costs if they do not.

In order to support the self-financed students, the government has complemented the existing student loan system with additional - more subsidised - loans to cover tuition fees. The interest rate is a fixed $2 \%$, against a higher and variable rate (8\% in 2012) in the existing scheme. In both schemes, the repayment schedule is wagecontingent, but the total amount to be reimbursed is not.

Budgets of institutions will be based on their actual, rather than potential, number of state-financed students. This gives universities greater incentive to attract students. It will also put important financial pressure on less prestigious universities, generally smaller and outside Budapest, which are less likely to fill their capacity. These universities have seen the largest declines in the number of students. Over $2011-13$, admissions declined by $22 \%$ in the 10 largest universities and $33 \%$ in the other 39 universities.

Several governance reforms have increased government influence. Heads of public tertiary education institutions will no longer be directly elected by the assemblies (senates) representing university stakeholders (e.g. university staff, teachers, students), but picked by the government from a list established by the senate. Internal auditors and economic directors will also be appointed by the government. Government influence over the committee giving accreditation to academic programmes was also reinforced. In addition, the capacity limits of detailed study programmes will be subject to government approval.

A monitoring system was introduced in 2009 to collect and publish information about the labour market outcomes of university graduates. As foreseen in the 2011 law on higher education, this information should be used more intensively by the authorities in decisions to favour certain fields of study over others. For example, state-financed access to 16 programmes in law, economics, social sciences and humanities was sharply restricted in 2012 in an attempt to steer potential students towards engineering and natural sciences (although the number of students in these specialties also declined in 2012-13). The array of available indicators indeed suggests a relative oversupply of graduates in social sciences and possibly humanities, but not clearly so in law and economics, although graduate prospects have been deteriorating in the latter (Table 3; Varga, 2013). Further, promoting scientific careers would also require strengthening scientific studies in primary and secondary schools.

An obstacle to participation in tertiary education may be that disadvantaged students are too risk-averse to finance their tuition with student loans, even though the loan reimbursement schedule is income contingent. The creation in 2012 of additional loans, with a greater degree of subsidy, to cover tuition costs may help in this respect (Box 4). If they do not succeed in raising participation of disadvantaged students, especially in programmes with few state-financed positions, a further step should be to extend the state financing of studies to all disadvantaged students meeting admission criteria. This could be financed by extending tuition fees (coupled with student loans) to more of the better-off students, which would be unlikely to deter them from enrolling given the high wage premium on university studies. 
Table 3. Tertiary education: labour market prospects per field of study

Better (+) or worse (-) student prospects than in the average of fields (2010 graduates)

\begin{tabular}{lccccc}
\hline & $\begin{array}{c}\text { Employment } \\
\text { rate }\end{array}$ & $\begin{array}{c}\text { Unemployment } \\
\text { rate }\end{array}$ & $\begin{array}{c}\text { Time to find } \\
\text { first job }\end{array}$ & Earnings & $\begin{array}{c}\text { Matching of job } \\
\text { with degree subject }\end{array}$ \\
\hline Agriculture & + & - & n.d. & - & - \\
Economics & + & + & - & + & + \\
Humanities & - & - & $=$ & + & - \\
Information technology & + & + & + & - & + \\
Law and administration & + & - & $=$ & - & + \\
Medical and health sciences & - & + & $=$ & - \\
Natural sciences & - & - & - & - & + \\
Social sciences & - & - & - & - & + \\
Technology (engineering) & + & + & & - & - \\
\hline
\end{tabular}

1. Unweighted average of bachelor and master level.

Source: J. Varga (2013), "Labour Market Success of Hungarian Higher Education Graduates in 2011”, in Hungarian Graduates 2011, Educatio Public Services, Ministry for Human Resources.

How to read this table: Economics graduates have a higher employment rate and a lower unemployment rate than the average of graduates. They take on average more time to find a first job, but have higher average earnings and their job more often matches with their field of study than the average of graduates.

To enhance the quality of tertiary education, there is room to further rationalise supply. Many institutions operate at a small scale, cover too many topics and may offer education of relatively low quality (OECD, 2010f). The reform of university financing was a positive step as it reduced the potential for courses with very few students, contributing to reduce sharply the number of programmes offered by universities, to still more than 500 in 2013. The logical continuation would be to close certain small institutions or merge them with larger ones. As these institutions are mainly in smaller towns or cities outside Budapest, care should be taken to not restrict participation of local students, especially with a disadvantaged background. To this end, scholarships could be put in place to facilitate their studying in larger cities. There may also be room to develop short-cycle "type B" tertiary programmes focusing on practical, technical and occupational skills, which can provide good employment outcomes and are less developed than in many OECD countries (OECD, 2012a). New two-year vocational programmes (felsöoktatási szakképzés) were launched with this purpose in 2013.

The 2012 reform has markedly reduced the autonomy of tertiary education institutions (Box 4). Although greater accountability in terms of educational and financial results was needed - including the right to intervene directly in problematic cases - a certain level of autonomy can stimulate dynamism and creativity (OECD, 2008b). Autonomy can also help develop partnerships with private companies, which can facilitate the labour market transition of students. In this specific case, the reduced autonomy may also hamper the flexibility of universities to adapt to the new financing rules that give them more incentives to attract students. As these new rules mean that institutions will be under more pressure from student choices - the authorities emphasise the importance of market-like mechanisms in this area - there should rather be less need for direct government control. In a welcome step, the authorities intend to restore a greater degree of autonomy in 2014 , by reducing government influence in the nomination of university directors. 


\section{International migration and the global competition for skills}

\section{Rising emigration prompts fears of skill shortages}

Hungary is traditionally a relatively low migration country (Hárs, 2009). Over recent years, emigration has sharply increased - while remaining lower than in some other eastern European countries reflecting weaker economic prospects at home and the gradual opening of EU labour markets to Hungarian citizens (Figure 13; note that emigration flows are likely to be underestimated by certain migrants still declaring residence in Hungary). Germany, Austria and more recently the United Kingdom are the main destinations. Looking ahead, surveys suggest an increasing willingness to emigrate, especially among young adults, and high-skilled emigration may increase further as the global competition for skills intensifies. Rising emigration is prompting fears of skill shortages. For now, these have materialised only in healthcare. Roughly one sixth of doctors may have left the country since the mid-2000s, a trend which, if continued, could rapidly lead to deficiencies in care supply (OECD, 2012a). On the other hand, emigration can also bring economic benefits in the form of remittances (1.8\% of GDP in 2012), trade networks and skills. Skills accumulated abroad can spill into the domestic economy and bring productivity gains if migrants return after some time. An illustration is that returning migrants command a wage premium of around 30\% in Hungary (Martin and Radu, 2012).

\section{Figure 13. Migratory trends}

Per 1000 population

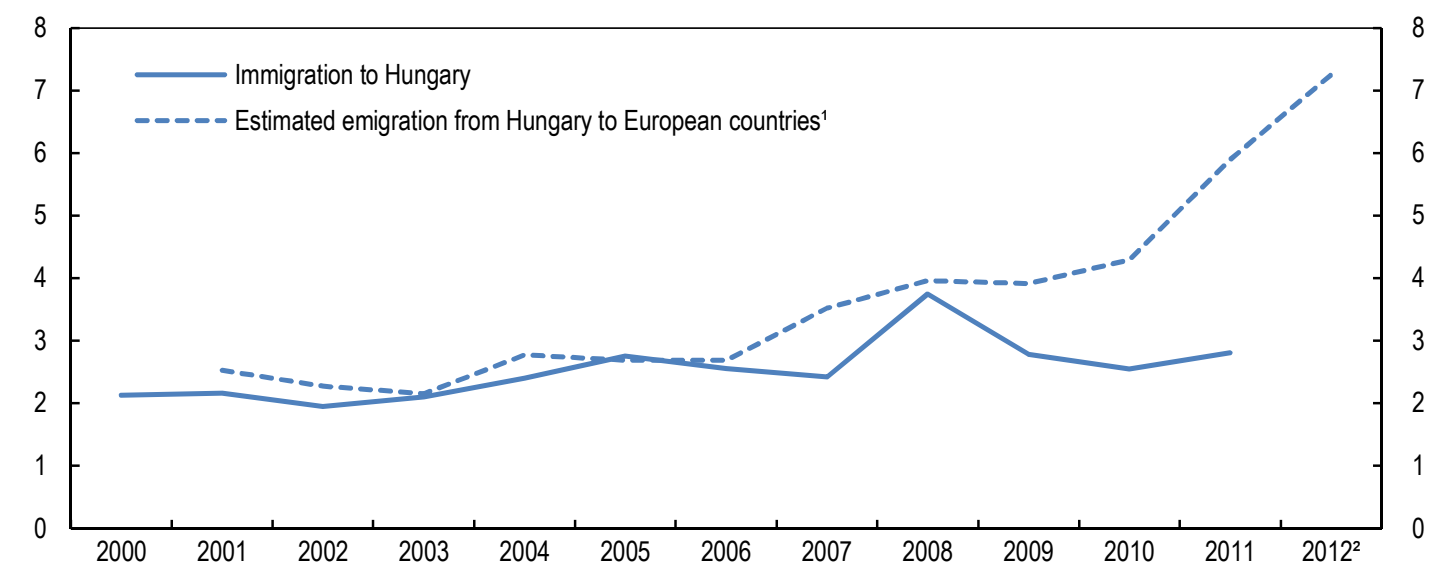

1. Based on "mirror" statistics, that is the number of Hungarian citizens registered as immigrants in the host countries. 2. Estimate.

Source: Eurostat (2013), "Population and Social Conditions", Eurostat Database, December and SEEMIG (2013), "South East Europe and Hungary - Migratory Trends", South East Europe Transnational Cooperation Programme.

Rising emigration can signal the need to improve the socio-economic situation and the business environment, as discussed in Pina (2014). In areas of potential skill shortages, especially healthcare, where the job vacancy rate is more than double the economy-wide average, targeted measures are needed to ensure sufficient labour supply. As recommended in the health chapter of the 2012 Survey (OECD, 2012a; Eris, 2012), wages of health professionals were increased substantially, by around $10 \%$ to $15 \%$ in 2012 depending on the data source (with larger increases for doctors), and about $7 \%$ in the first 10 months of 2013 according to the Central Statistical Office. However, they remain low in a European perspective. As emigration of health professionals has only stabilised, at a high rate, in 2012, further substantial wage increases and improvements in working conditions for doctors and nurses will be needed to bring down emigration rates and maintain adequate supply. A more specific issue is the system of "practice rights" 
(praxisjog), which complicates the entry of young family doctors into the system and thus encourages them to emigrate. As recommended in the 2012 Survey, this system should be phased out (OECD, 2012a).

As a way to moderate high-skilled emigration, or at least to make emigrants contribute more to their education costs, higher education students benefitting from state-financed tuition are now required to work in Hungary for a period equal to the duration of their studies over their first 20 years of career (Box 4). The effect of the measure on emigration may remain limited, as the implementation of potential sanctions (the reimbursement of tuition costs) is uncertain and will only start in 20 years, making it conditional on the scheme remaining in place over the period. An unintended consequence, not necessarily negative, is also that some students may decide to study abroad to remain free from any future geographic constraints.

\section{Attracting high-skilled immigration, including by returning migrants}

There may be scope to attract more high-skilled immigration, including by Hungarians returning after a few years, to offset potential skill shortages and enhance the potential of the economy. The share of returning migrants, although difficult to observe, may have declined over recent years (SEEMIG, 2013). Immigration is relatively low, and largely comes from ethnic Hungarians in neighbouring countries - a tendency that the 2011 law may reinforce as it gave them easier access to Hungarian nationality, with about 100000 people benefitting. The low immigration reflects the language barrier, but also until 2013 the lack of a national immigration strategy and possibly a relatively high incidence of xenophobia (Hárs and Sík, 2008; Hárs, 2009). More recently, the deterioration of the socio-economic situation and certain measures affecting more heavily foreign-owned companies, such as some special taxes on specific sectors, may also have weighed on high-skilled immigration.

Targeted schemes combining easier visa requirements, language courses, support for administrative procedures and possibly tax incentives could be introduced to attract migrants in potential areas of skill shortage. However, potential negative consequences on the labour force of origin countries, especially in the healthcare sector, should be taken into account, potentially requiring cooperation with these countries. For non EU citizens, visa and working permit requirements can still represent a substantial barrier. In particular, potential employers have to prove that no Hungarian jobseeker is suitable for the job and working permits last for a maximum of only two years. The introduction of the EU blue card (a work permit for high-skilled non-EU citizens) has not helped in this respect, as Hungary has set very high minimum wage requirements for such immigrants (120-150\% of the average wage of the sector), resulting in almost no take up (Busch et al., 2013). More recent efforts include steps to simplify administrative processes, including joint application to visa and work permit for non EU citizens, and an information package for immigrants in the health sector.

Tax privileges for immigrants, including returning emigrants, exist in many OECD countries (Dumont and Lemaitre, 2005). For example, the Netherlands offers high-skilled expatriates in the country a $30 \%$ income tax break and Israel has recently broadened tax privileges of immigrants and extended them to returning migrants. In Hungary, the relatively low income tax rate on high incomes represents a form of tax incentive, although relatively high social security contributions mean that the tax wedge on high incomes is above the OECD average. Also, researchers with a $\mathrm{PhD}$ in science are eligible to tax relief.

Further attracting foreign students could also contribute to high-skilled immigration. Depending on the country, it is estimated that $15 \%$ to $30 \%$ of them stay after their studies (OECD, 2011a). The number of foreign students in Hungarian universities has nearly doubled since 2000, although it remains below the OECD average (Figure 14). However, an important share of them are medical students, who sometimes come to avoid student quotas in their countries and generally have little interest in staying in Hungary afterwards. Growth in the number of foreign students was supported by the transition to the Bologna qualification system, the development of the Erasmus programme, the introduction of the Campus Hungary 
programme and the increasing availability of courses in English. The fact that foreign students can benefit from state-financed tuition - a third of them did in 2011 - also helps. The authorities should further push to attract foreign students, and are designing a new strategy with this purpose.

\section{Figure 14. International and foreign students ${ }^{1}$}

Per cent of all tertiary enrolment, $2011^{2}$

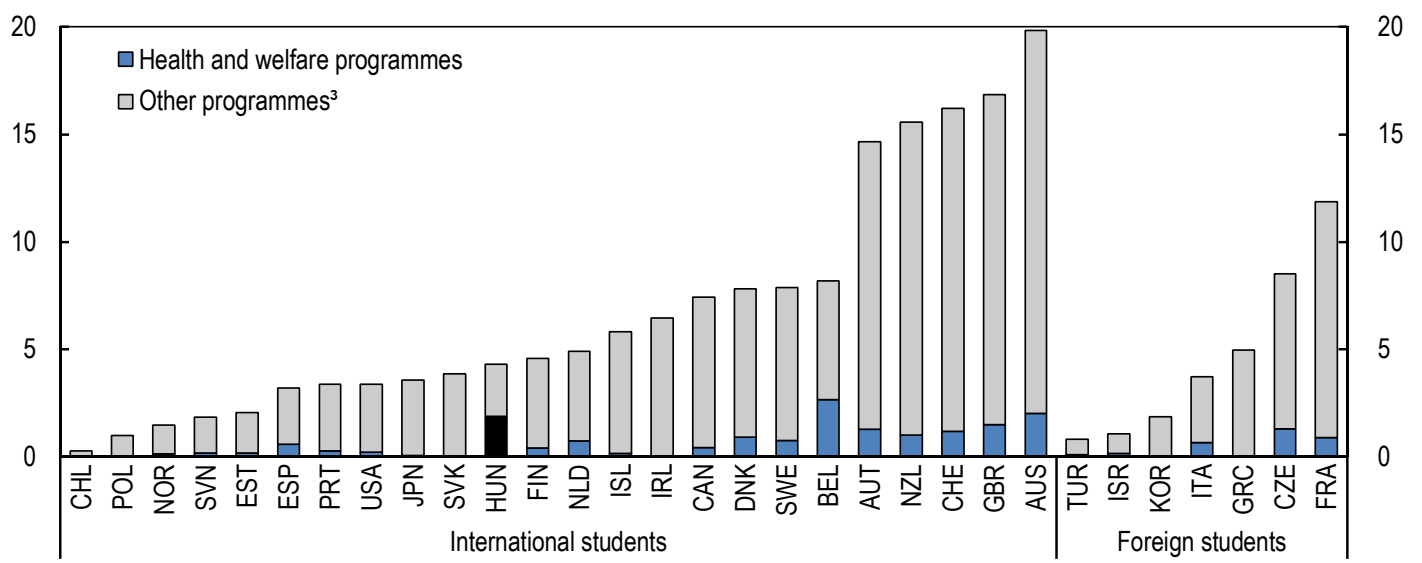

1. International students are students who have crossed borders expressly to study. Foreign students are non-citizens of the country for which the data are collected. These two sets of data are not comparable and therefore are presented separately. For further details of data coverage see Tables C4.1 and C4.2 of the source publication.

2. 2010 for Canada.

3. All programmes for countries where no health and welfare breakdown is available.

Source: OECD (2013), Education at a Glance 2013: OECD Indicators.

\section{A more flexible housing market would facilitate the relocation of workers}

Internal migration is taking place from job-poor areas in the south and east of the country, to job-richer ones around Budapest and near the Austrian border. However, the pace of migration over the past decade has been insufficient to reduce the large regional differences in unemployment. Increasing the mobility of workers, both in terms of relocating and commuting, has significant potential to increase employment. A risk is that workers leaving job-poor areas may further depress activity there, adding to geographic inequalities. Efforts to relocate activity to disadvantaged areas, such as the recent creation of "free enterprise" low-tax zones, can help mitigate this risk. Take-up to these new zones has started slowly - the authorities assess that 400 jobs were created (or shifted) in the first half of 2013 - and further measures may be necessary to encourage activity to relocate, such as, as discussed above, moving towards a lower minimum wage in disadvantaged areas.

\section{The high homeownership rate is an obstacle to mobility}

Housing mobility is very low in Hungary, reflecting the underdevelopment of the rental market, substantial transaction costs and, more recently, high mortgage indebtedness of certain households (Figure 15; Andrews et al., 2011). The lack of a rental market is particularly detrimental to relocating workers as house prices are much higher in job-rich areas, particularly Budapest. In this respect, a relocation subsidy launched in 2012 for 500 selected workers may help, but only at the margin. The homeownership rate has been extremely high since the transition to a market economy, when dwellings were sold to tenants at a large discount. Younger generations, who have not benefitted, have much poorer housing conditions and often need parental support to buy a house (Giday, 2011). Since the transition, the development of a rental market was never really encouraged. Homeownership was always strongly tax and subsidy-favoured and the social rental market is almost non-existent. The informal rental market is 
generally estimated to represent roughly two thirds of the total rental market. Tax avoidance is the main reason for informality, even though net rental income is subject only to the $16 \%$ personal income tax. Informality (and the associated tax evasion) poses fairness issues, creates risks for both landlords and tenants by reducing scope for legal action in case of dispute and can deprive tenants of an official address.

Figure 15. Housing market
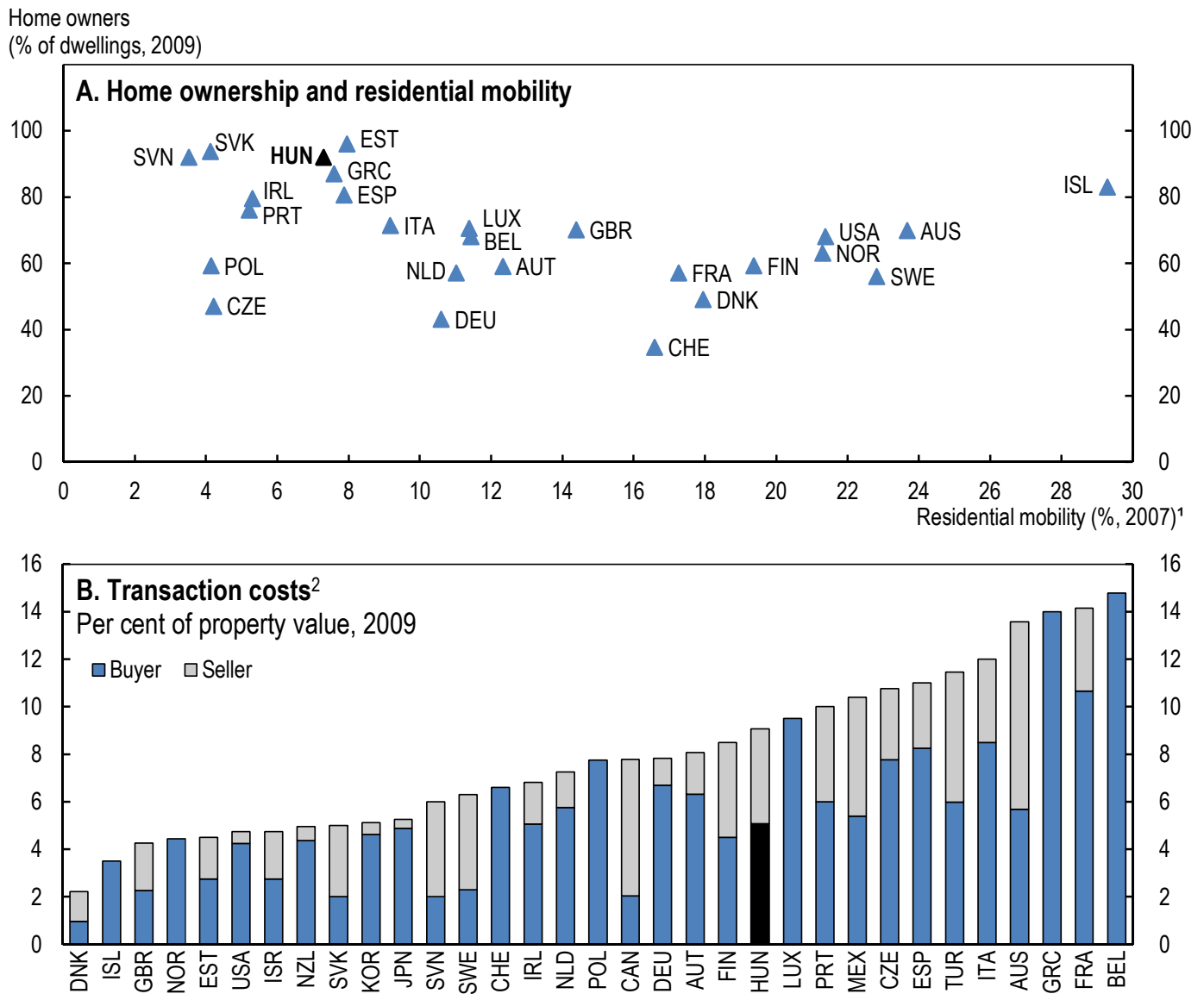

1. Percentage of households that changed residence within the last two years. The low mobility rate in some Eastern European countries may reflect problems with the underlying data. However, this is difficult to verify as there is no alternative data source.

2. Average costs including notary fees, typical real estate agent fees, legal fee, registration fees and transfer taxes (e.g. stamp duties).

Source: D. Andrews, A. Caldera Sánchez and Å. Johansson (2011), "Housing Markets and Structural Policies in OECD Countries", OECD Economics Department Working Papers, No. 836.

\section{Encouraging the development of a formal rental market}

The development of the formal rental market should be encouraged by reducing the bias towards homeownership induced by taxation and mortgage interest subsidies. The current combination of low recurrent property taxes $(0.3 \%$ of GDP in 2010, against an OECD average of $1.0 \%$ of GDP) and generous mortgage interest subsidies on loans in forint $(50-70 \%$ of the interest is paid by the government in the first five years of contract) is very favourable for homeowners. In general, mortgage interest subsidies do not strongly expand housing opportunities, because they partly translate into higher prices, but tend to be costly, regressive and favour excessive leverage (Andrews et al., 2011). 
In theory, the best solution to make housing taxes and subsidies neutral vis-à-vis other investments would be to tax homeowners on their imputed rents, while allowing them to deduct mortgage interest from their income tax (OECD, 2011b). In practice, only a few countries tax imputed rents and those that do substantially underestimate rental values. A more practical solution would be to gradually raise recurrent property taxes (as a substitute for taxing imputed rents) and phase out mortgage interest subsidies. The proceeds could serve, among others, to reduce the $4 \%$ housing transaction tax. Regarding the phasing out of interest subsidies, an exception could be made in the short run for the purchase of new dwellings to avoid further depressing the construction sector. In 2003, sharp cuts in subsidies for forint-denominated mortgages contributed to a wave of excessive borrowing in foreign currency (Banai et al., 2011). However, such an outcome would be much less likely this time, thanks to much stronger regulation of foreign currency borrowing.

Recurrent property taxes are generally considered among the least harmful for economic growth, but often pose political issues (Cournède et al., 2013; Norregaard, 2013). In Hungary, several property taxes are levied at the municipal level. The most important is the residential building tax, which only less than $20 \%$ of municipalities have opted to levy. The tax rate is set by municipalities, with a maximum of HUF 1722 per square meter or $1.8 \%$ of the assessed market value of the property. A national tax on properties worth more than HUF 30 million was briefly introduced in 2010 and abandoned after its design was judged unconstitutional. To enhance political adhesion to higher property taxes, and taking into account the very high homeownership rate, care should be taken in assessing the impact on poverty and in offering solutions to the asset-rich but income-poor (mostly elderly) people who would be most affected, for example life-annuity property sales, where the buyer pays a regular sum to the seller and receives the property when the seller dies.

Informal renting is currently widely tolerated. Improving the regulatory environment to reduce uncertainties for potential landlords would encourage formality and should be combined with more effective tax controls to discourage informality. Eviction of a tenant who has ceased to pay rents can be difficult and lengthy. It involves a court trial and a procedure that can take up to two years in Budapest. This should be simplified and greatly shortened for cases with cause, such as non-payment of rent. Reducing the scope for conflict around utility bills would also help. Bills are often paid by tenants, but utility contracts are generally in the name of the landlord, who is ultimately responsible in case of unpaid bills. Contracts should rather be transferred to tenants, or provisions for utility bills should be included in the rents.

\section{Enhancing the quality of housing conditions}

The quality of housing is relatively poor (Hegedüs et al., 2009). Overcrowded dwellings are much more common than in most EU countries, especially among younger generations, which may contribute to the low birth rate. Many buildings, notably those built during the communist era, lack maintenance and have poor insulation. Renovation work has slowed as many homeowners struggle with high indebtedness (Giday, 2011). Increasing taxation of energy use and generalising individual meters would give greater incentive to enhance energy efficiency (Energiaklub, 2011; Pina, 2014). It would also bring funds that could be used, along with already existing EU funds, to further support such renovation works. To improve the housing conditions of the poorest, developing social housing should also be considered. The starting point for a national social housing system could be the National Asset Management Agency (NAMA), which in 2012 started buying properties from (and then letting to) socially vulnerable borrowers with excessive indebtedness. 


\section{Improving the efficiency of transport to reduce commuting costs}

Commuting by public transport is more common in Hungary than in neighbouring countries (Paci et al., 2007), but there is room to develop it further by making transport more efficient. This would facilitate labour market matching and stimulate employment in rural areas, which strongly depends on commuting costs (Bartus, 2012). A 30 kilometre monthly train or bus ticket costs about EUR 70, 20-70\% more than in other Visegrád countries. Still, many workers commute by public transport, reflecting a lower car ownership than in most OECD countries and a very dense public transport network, although the network would benefit from better integration between transport modes. The road network has been expanded over recent years with new EU-cofinanced highways, but it can be very congested during peak hours in Budapest. Low investment in maintenance has resulted in deteriorating road and rail infrastructures, forcing trains to reduce speed on some lines (Persson and Song, 2010; State Audit Office, 2012a and 2012b).

Workers and jobseekers can benefit from transport subsidies. Companies are required to finance $86 \%$ of their workers' commuting costs if they commute by train or intercity bus. However, the effect on employment is unclear and may even be negative, as this represents an additional labour cost for companies.

\section{There is significant scope for efficiency gains in public transport provision}

Until 2012, the public transport sector ran persistent operating losses and accumulated debts, which were periodically taken over by the central government. In 2012, an operational surplus was achieved, but this reflected higher government subsidies (1.2\% of GDP in 2012, mainly to the railway company) more than efficiency gains, as there has been considerable delay in the implementation of efficiency-enhancing measures in the Szell-Kalman plan (European Commission, 2013b). In general, subsidising public transport can be economically justified as it generates positive externalities relative to travelling by car. However, it is important that subsidies be transparently set in advance in return for an agreed level of service and that the government take rapid corrective action if that contract is not fulfilled (OECD, 2011c). The new medium-term budgeting system for train and inter-city bus companies introduced in 2012 goes in this direction. In such an arrangement, subsidies could be gradually reduced over coming years to push the public transport companies to achieve efficiency gains.

A very dense railway network was inherited from the communist era and traffic on certain train lines is low. Some lines could probably be replaced efficiently by bus services (GKI, 2012). A few lines were closed in the late 2000s, but some were reopened in 2010. In recent years, train circulation was reduced on many lines, while some timetable and tariff modifications have aimed at attracting more passengers. The costs and benefits of keeping low-traffic lines open should be assessed and the results made public. Closing some low-traffic lines would allow better targeting of the scarce maintenance funds, could bring environmental benefits, especially as certain lines are not electrified, and could allow reduced staffing, as it is generally considered ample. In addition, there may be room to renegotiate working conditions of employees to bring them closer to equivalent private sector occupations. For example, train and intercity bus drivers are among the very few occupations that can still retire early, as they have to contribute $20 \%$ less time than other workers to receive the same pension. The governance structure of the railway company (MÁV) should also be reviewed, as envisaged by the authorities, as the division into several sub-entities a few years ago increased the number of management positions, and thus costs, without a clear effect on efficiency (State Audit Office, 2012a).

The very dense network of government-owned intercity buses (Volán) connects poorer people in remote areas to services and potential employment in larger towns. However, efficiency could be enhanced as the size of buses is not always adapted to the traffic load and the company is fragmented into 24 small 
independent entities operating at the local level (GKI, 2012). The authorities intend to merge these into seven regional providers, which should help rationalise supply, bring economies of scale and facilitate coordination. In the medium run, there are plans to privatise these providers and open the market to new entrants to comply with EU requirements, which may enhance competition and efficiency. To preserve coverage of remote areas, a transparent procurement framework should be put in place where companies compete for public service obligation subsidies.

Progress has been made in rationalising the Budapest public transport system. A holding company (BKK) was created in 2010 that represents the municipality and subcontracts transport provision mainly to BKV (the historical provider, which BKK supervises). The operation of about $20 \%$ of bus lines has been delegated to a private operator (VT Transman) and the intercity bus company (Volán). This new governance structure may bring efficiency gains as companies regularly have to compete in open tenders for the attribution of the different bus lines, although participation has remained limited so far. Also in 2010, working contracts have been renegotiated in BKV (for instance lunch break time is no longer paid), contributing to $5 \%$ savings. Nevertheless, there remains scope for further efficiency gains, as envisaged, by introducing electronic metro gates and integrated electronic ticketing.

\section{Towards fairer and greener transport}

The important government-financed discounts for specific groups in public transport contribute indirectly to higher costs for other passengers, such as commuting workers (Table 4). In trains, there are more than 40 different discounts and only $40 \%$ of passengers pay the full price. Certain discounts, such as those for large families and elderly people, appear very high internationally. This calls for reassessing the socio-economic justification of the different discounts and, as a minimum, means-testing them to target only poorer households. The associated savings could be used to reduce prices for other passengers and improve the fiscal position.

Table 4. Main discounts in public transport

\begin{tabular}{|c|c|c|c|}
\hline & Railways (MÁV) & Intercity buses (Volán) & $\begin{array}{l}\text { Budapest public } \\
\text { transport (BKK) }\end{array}$ \\
\hline Elderly people (over 65) & $100 \%$ & $100 \%$ & $100 \%$ \\
\hline Pensioners (below 65) & $\begin{array}{l}90 \% \text { on } 2 \text { trips per year, } \\
50 \% \text { on } 16 \text { trips per year }\end{array}$ & $\begin{array}{l}90 \% \text { on } 2 \text { trips per year, } \\
50 \% \text { on } 16 \text { trips per year }\end{array}$ & $65 \%^{1}$ \\
\hline Children (below 6) & $100 \%$ & $100 \%$ & $100 \%$ \\
\hline Children (aged 6-14) & $50 \%$ & $50 \%$ & . \\
\hline Students & $\begin{array}{l}90 \% \text { between school and } \\
\text { home, } 50 \% \text { otherwise }\end{array}$ & $\begin{array}{l}90 \% \text { between school and } \\
\text { home, } 50 \% \text { otherwise }\end{array}$ & $63 \%^{1}$ \\
\hline Young people (below 26) & $\begin{array}{l}33 \% \text { between Friday and } \\
\text { Sunday }\end{array}$ & . & $\cdots$ \\
\hline Disabled people and accompanier & $90 \%$ & $90 \%$ & $100 \%$ \\
\hline $\begin{array}{l}\text { Large families (travelling with at } \\
\text { least } 3 \text { children) }\end{array}$ & $90 \%$ & $90 \%$ & . \\
\hline $\begin{array}{l}\text { Adult accompanying at least one } \\
\text { child below } 18\end{array}$ & $33 \%$ & . & . \\
\hline Civil servants & $\begin{array}{l}50 \% \text { on } 12 \text { round trips } \\
\text { per year }\end{array}$ & $\begin{array}{l}50 \% \text { on } 12 \text { round trips } \\
\text { per year }\end{array}$ & $\ldots$ \\
\hline
\end{tabular}

1. Only for passes of a duration of at least one month.

Source: MÁV, Volán and BKK websites, June 2013. 
Greenhouse gas emissions from the transport sector are higher than a decade ago, although they have declined during the economic crisis, and local air pollution in Budapest is harmful for health (Figure 16). In an environmental perspective, the relatively high reliance on public transport is positive. However, the relatively old age of the rolling stock - both in public and private transport - is contributing to pollution. In Budapest, $20 \%$ of the public bus fleet is being renewed.

Figure 16. Transport and the environment
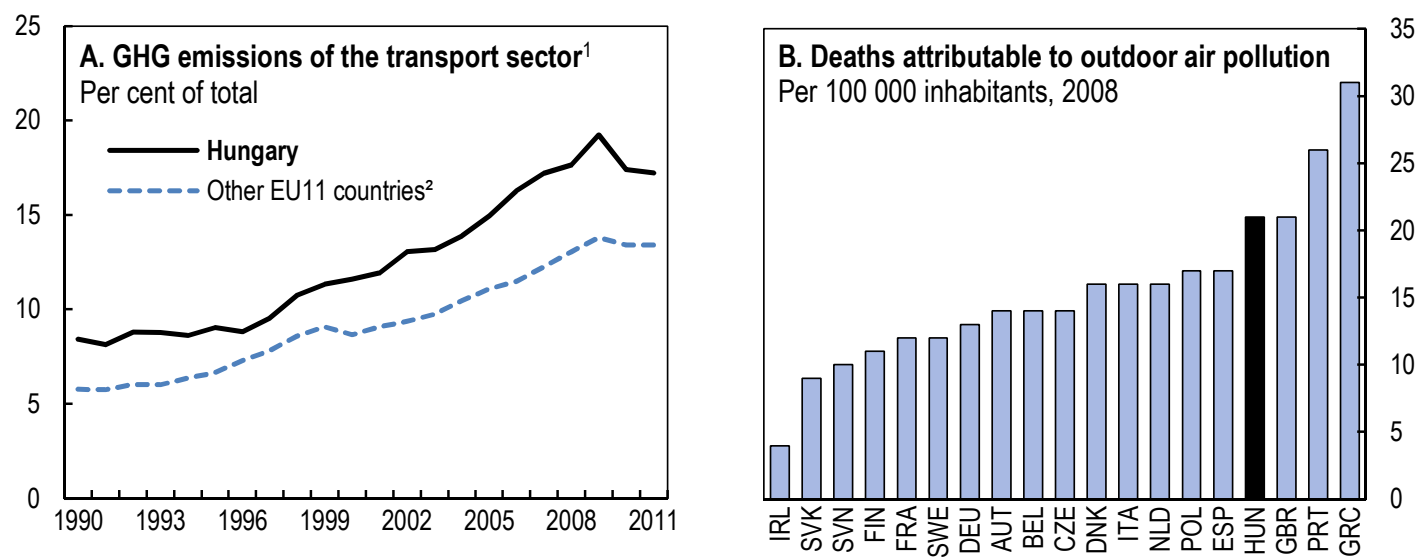

1. Net greenhouse gas (GHG) emissions/removals, excluding land use, land-use change and forestry (LULUCF).

2. EU11 is a weighted average of other Central and East European countries that are members of the European Union (Bulgaria, Czech Republic, Croatia, Estonia, Latvia, Lithuania, Poland, Romania, Slovak Republic and Slovenia).

Source: UNFCCC (2013), "GHG Data - UNFCCC", United Nations Framework Convention on Climate Change and WHO (2013), Global Health Observatory Data Repository.

More should be done to internalise the negative externalities of private transport in terms of pollution and congestion. Vehicle registration taxes take into account environmental performance, but annual vehicle taxes do not fully do so, as they decline with vehicle age, which can slow fleet renewal and contribute to pollution (OECD, 2008c). The average age of the vehicle fleet is relatively high $-12 \frac{1}{2}$ years in 2012 , up by two years since 2008 (HCSO, 2013). Diesel cars represented 54\% of first time car registrations in 2012, more than twice the share ten years ago. Taxation of diesel should be further increased relative to gasoline (though the difference is already lower than in many OECD countries), as envisaged, to reflect that diesel engines, despite being more fuel-efficient, emit more particulate matter that is harmful for health. On the positive side, an electronic toll system for trucks on main roads was launched in 2013, which will contribute to internalise their negative externalities in terms of wear-and-tear and pollution. A road pricing scheme for private vehicles in Budapest, on the model of London, was considered in 2010 but abandoned. Such a scheme would help reducing congestion - especially if user charges are higher at peak hours - and pollution, although it would require additional investments in public transport to accommodate shifting demand.

\section{Box 5. Main recommendations to tackle labour market mismatches and promote mobility}

\section{Stimulate demand for low-skilled labour}

- $\quad$ Further reduce the tax wedge on low salaries to stimulate low-skilled employment. Target existing cuts in social security contributions (Job Protection Act) exclusively on low salaries.

- Refrain from increasing the minimum wage by more than warranted by inflation and productivity developments, and consider even freezing it for some time. Consider moving progressively towards a lower minimum wage in disadvantaged regions. 


\section{Upgrade workers' skills through enhanced active labour market policies and lifelong learning}

- Enhance reintegration of public workers through carefully evaluated training, local cooperation between municipalities, job centres, non-governmental organisations and private firms, and further support to microentrepreneurship. Give municipalities medium-term financial incentives to reintegrate participants to the labour market.

- Scale up the capacity of the Public Employment Service in terms of staffing and efficiency. Increase somewhat the duration of unemployment benefits. Ensure monitoring and enforcement of job search requirements.

- Evaluate the efficiency of training programmes for the unemployed, publish the results, and involve the unemployed more in the choice of their training provider.

Reform education to reduce inequalities and better meet labour market needs

\section{Primary and secondary education}

- Tackle school segregation by sending pupils in small rural schools to more socially diverse schools in larger towns. Target more resources to disadvantaged schools and give teachers more financial incentives to work in disadvantaged areas.

- Preserve the functional and pedagogic autonomy of schools, but reinforce benchmarking to enhance accountability.

- Postpone tracking to enhance the general skills of pupils and their future adaptability to change jobs.

\section{Tertiary education}

- Encourage participation of disadvantaged students by extending the state financing of studies to all disadvantaged students meeting admission criteria.

- Use the information collected on labour market outcomes of students more intensively in the allocation of state-financed (no tuition fees) positions across fields of study.

Attract high skilled migration to prevent skill shortages

- Combine easier visa requirements, language courses, support for administrative procedures and possibly tax incentives to attract high-skilled immigrants in potential skill shortage domains.

Enhance the flexibility of the housing market to facilitate the relocation of workers

- Encourage the development of the rental market by gradually phasing out mortgage interest subsidies and increasing recurrent municipal property taxes.

- Improve the regulatory environment of rental contracts by simplifying and shortening eviction procedures.

Improve efficiency in the transport sector to reduce commuting costs

- $\quad$ Finance the public transport companies transparently with pre-determined annual subsidies in exchange for an agreed level of service. Gradually reduce subsidies over the coming years to push for efficiency gains.

- Assess the costs and benefits of keeping low-traffic train lines open and publish the results. Where justified, replace them by bus services, which would be cheaper.

- Reassess public transport discounts to specific groups, so as to reduce transport costs for other travellers. 


\section{Bibliography}

Andrews, D., A. Caldera Sánchez and A. Johansson (2011), "Housing Markets and Structural Policies in OECD Countries", OECD Economics Department Working Papers, No. 836, OECD Publishing, http://dx.doi.org/10.1787/5kgk8t2k9vf3-en.

Banai, A., J. Király and M. Nagy (2011), "Home High Above and Home Deep Down Below - Lending in Hungary", Policy Research Working Paper, No. 5836, World Bank.

Bartus, T. (2012), "Commuting and Spatial Variation in Employment", in K. Fazekas and A. Schorle (eds.), From Pensions To Public Works - Hungarian Employment Policy From 1990 To 2000, Budapest Institute for Policy Analysis and Institute of Economics, Hungarian Academy of Sciences.

Benedek, D., G. Kátay and Á. Kiss (2013a), "Microsimulation as a Tool for Assessing the Impact of Tax Changes", in K. Fazekas et al. (eds) (2013), The Hungarian Labour Market, 2013, Centre for Economic and Regional Studies, Hungarian Academy of Sciences and National Employment Non-Profit Public Company Ltd.

Benedek, D., P. Elek and J. Köllő (2013b), “Tax Avoidance, Tax Evasion, Black and Grey Employment”, in K. Fazekas et al. (eds) (2013), The Hungarian Labour Market, 2013, Centre for Economic and Regional Studies, Hungarian Academy of Sciences and National Employment Non-Profit Public Company Ltd.

Blöchliger, H., B. Égert and K. Bonesmo Fredriksen (2013), "Fiscal Federalism and its Impact on Economic Activity, Public Investment and the Performance of Educational Systems", OECD Economics Department Working Papers, No. 1051, OECD Publishing, http://dx.doi.org/10.1787/5k4695840w7b-en.

Boeri, T. and M. Macis (2010), “Do Unemployment Benefits Promote or Hinder Job Reallocation?”, Journal of Development Economics, Vol. 93, No. 1, Elsevier, http://dx.doi.org/10.1016/j.jdeveco.2009.04.002.

Budapest Institute (2013), Targeting and Impact Evaluation of EU-Funded Active Labour Market Programmes, Budapest Institute for Policy Analysis.

Budapest Institute (2011), The Efficiency of Municipal Public Works Programmes, Budapest Institute for Policy Analysis.

Busch, I., Z. Cseres-Gergely and L. Neumann (2013), "Institutional Environment of the Labour Market between September 2011 and August 2012", in K. Fazekas et al. (eds) (2013), The Hungarian Labour Market, 2013, Centre for Economic and Regional Studies, Hungarian Academy of Sciences and National Employment Non-Profit Public Company Ltd.

Card, D., J. Kluve and A. Weber (2010), “Active Labour Market Policy Evaluations: A Meta-Analysis”, NBER Working Paper, No. 16173, National Bureau for Economic Research.

Cedefop (2009), "Individual learning accounts", Cedefop Panorama series, No. 163, Luxembourg: Office for Official Publications of the European Communities. 
Cournède, B., A. Goujard, Á. Pina and A. de Serres (2013), "Choosing Fiscal Consolidation Instruments Compatible with Growth and Equity", OECD Economic Policy Papers, No. 7, OECD Publishing, http://dx.doi.org/10.1787/5k43nxq6dzd4-en.

Csapó, B. (2009), "The Second Stage of Public Education and the Matura”, in Green Book for the Renewal of Education in Hungary, Ecostat Government Institute for Strategic Research of Economy and Society.

Cseres-Gergely, Z. (2010), EEO Review: Youth Employment Measures, European Employment Observatory.

Dumont, J. and G. Lemaître (2005), "Counting Immigrants and Expatriates in OECD Countries: A New Perspective", OECD Social, Employment and Migration Working Papers, No. 25, OECD Publishing, http://dx.doi.org/10.1787/521408252125.

Energiaklub (2011), "NEGAJOULE2020 - Energy Efficiency Potential of Hungarian Residential Buildings", Energiaklub Climate Policy Institute and Applied Communications.

Eris, M. (2012), "Improving Health Outcomes and System in Hungary", OECD Economics Department Working Papers, No. 961, OECD Publishing, http://dx.doi.org/10.1787/5k98rwqj3zmp-en.

European Commission (2013a), "The Skill Mismatch Challenge in Europe", in Employment and Social Developments in Europe 2012, http://dx.doi.org/10.2767/86080.

European Commission (2013b), "Assessment of the 2013 National Reform Programme and Convergence Programme for Hungary”, Commission Staff Working Document, SWD(2013) 367 final.

European Commission (2012), The European Higher Education Area in 2012: Bologna Process Implementation Report, Education, Audiovisual and Culture Executive Agency, http://dx.doi.org/0.2797/81203.

European Commission (2011), “Attitudes towards vocational training and education”, Special Eurobarometer, No. 369.

Fazekas, K. and A. Scharle (2012), "Structural Problems of the Hungarian Labour Market", in K. Fazekas and A. Scharle (eds), From Pensions To Public Works - Hungarian Employment Policy From 1990 To 2000, Budapest Institute for Policy Analysis and Institute of Economics, Hungarian Academy of Sciences.

Gautié, J. and C. Perez (2012), "Promoting Life Long Learning through Individual Accounts: from AssetBased to Capability-Based Policies", Documents de Travail du Centre d'Économie de la Sorbonne, No. 21.

Giday, A. (2011), “Home Tax Allowance for Younger People”, Public Finance Quarterly, No. 1, State Audit Office.

GKI (2012), “An Economic Recovery Plan For Hungary - A Blueprint of the Government's Actions for the 2014-2018 Period”, GKI Gazdaságkutató Zrt.

Government of the Republic of Hungary (2013), National Reform Programme of Hungary, April.

GVI (2012), “Diplomás pályakezdők a versenyszektorban - 2011” (Graduates in the private sector, 2011), Institute for Economic and Enterprise Research, Hungarian Chamber of Commerce and Industry. 
Harasztosi, P. (2011), "Growth in Hungary 1994-2008: The Role of Capital, Labour, Productivity and Reallocation”, MNB Working Papers, No. 12, Magyar Nemzeti Bank.

Hárs, A. (2009), "Immigration Countries in Central and Eastern Europe - The Case of Hungary", IDEA Working Paper, No. 12, Centre of Migration Research, Warsaw University.

Hárs, A. and E. Sík (2008), "Chapter 3 - Hungary”, in Permanent Or Circular Migration? Policy Choices to Address Demographic Decline and Labour Shortages in Europe, International Organisation for Migration (IOM), Regional Mission for Central and South Eastern Europe.

Havas, G. (2009), “Equality of Opportunity, Desegregation”, in Green Book for the Renewal of Education in Hungary, Ecostat Government Institute for Strategic Research of Economy and Society.

HCSO (2013), “Transport performances, Quarter 4 of 2012”, KSH Statistical Reflections, Vol. 7, No. 45, Hungarian Central Statistical Office.

Hegedüs, J., O. Eszenyi and N. Teller (2009), “Housing needs in Hungary”, Budapest Metropolitan Research Institute.

Jenkins, S.P., J. Micklewright and S.V. Schnepf (2008), "Social Segregation in Secondary Schools: How Does England Compare with Other Countries?", Oxford Review of Education, Vol. 34, No. 1, Routledge, http://dx.doi.org/10.1080/03054980701542039.

Karsten, S. (2010), "School Segregation", in Equal Opportunities?: The Labour Market Integration of the Children of Immigrants, OECD Publishing, http://dx.doi.org/10.1787/9789264086395-8-en.

Kertesi, G. and J. Köllö (2003), "Fighting “Low Equilibria” by Doubling the Minimum Wage? Hungary's Experiment", IZA Discussion Paper, No. 970, Institute for the Study of Labour.

Ladányi, T. and R. Kierzenkowski (2012), "Work Incentives and Recent Reforms of the Tax and Benefit System in Hungary", OECD Economics Department Working Papers, No. 944, OECD Publishing, http://dx.doi.org/10.1787/5k9d1969m56b-en.

Liskó, I. (2009), "Vocational Training and Early School Leavers", in Green Book for the Renewal of Education in Hungary, Ecostat Government Institute for Strategic Research of Economy and Society.

Martin, R. and D. Radu (2012), "Return Migration: The Experience of Eastern Europe", International Migration, Vol. 50, No. 6, Blackwell Publishing Ltd, http://dx.doi.org/010.1111/j.14682435.2012.00762.x.

Norregaard, J. (2013), “Taxing Immovable Property - Revenue Potential and Implementation Challenges", IMF Working Papers, No. 129,International Monetary Fund.

OECD (2013a), Education at a Glance 2013: OECD Indicators, OECD Publishing, http://dx.doi.org/10.1787/eag-2013-en.

OECD (2013b), Improving Education in Mexico: A State-level Perspective from Puebla, OECD Publishing, http://dx.doi.org/10.1787/9789264200197-en.

OECD (2012a), OECD Economic Surveys: Hungary 2012, OECD Publishing, http://dx.doi.org/10.1787/9789264127272-en. 
OECD (2012b), "Lifelong Learning and Adults", in Education Today 2013: The OECD Perspective, OECD Publishing, http://dx.doi.org/10.1787/edu_today-2013-9-en.

OECD (2012c), Education at a Glance 2012: OECD Indicators, OECD Publishing, http://dx.doi.org/10.1787/eag-2012-en.

OECD (2012d), Equity and Quality in Education: Supporting Disadvantaged Students and Schools, OECD Publishing, http://dx.doi.org/10.1787/9789264130852-en.

OECD (2011a), International Migration Outlook 2011, OECD Publishing, http://dx.doi.org/10.1787/migr_outlook-2011-en.

OECD (2011b), "Housing and the Economy: Policies for Renovation", in Economic Policy Reforms 2011: Going for Growth, OECD Publishing, http://dx.doi.org/10.1787/growth-2011-46-en.

OECD (2011c), OECD Guidelines on Corporate Governance of State-owned Enterprises, http://dx.doi.org/10.1787/9789264009431-10-en.

OECD (2010a), Off to a Good Start? Jobs for Youth, OECD Publishing, http://dx.doi.org/10.1787/9789264096127-en.

OECD (2010b), PISA 2009 Results: What Students Know and Can Do - Student Performance in Reading, Mathematics and Science (Volume I), OECD Publishing, http://dx.doi.org/10.1787/9789264091450en.

OECD (2010c), PISA 2009 Results: Overcoming Social Background - Equity in Learning Opportunities and Outcomes (Volume II), OECD Publishing, http://dx.doi.org/10.1787/9789264091504-en.

OECD (2010d), Closing the Gap for Immigrant Students: Policies, Practice and Performance, OECD Reviews of Migrant Education, OECD Publishing, http://dx.doi.org/10.1787/9789264075788-en.

OECD (2010e), PISA 2009 Results: What Makes a School Successful? - Resources, Policies and Practices (Volume IV), OECD Publishing, http://dx.doi.org/10.1787/9789264091559-en.

OECD (2010f), OECD Economic Surveys: Hungary 2010, OECD Publishing, http://dx.doi.org/10.1787/eco_surveys-hun-2010-en.

OECD (2008a), Learning for Jobs Review of Hungary 2008, OECD Reviews of Vocational Education and Training, OECD Publishing, http://dx.doi.org/10.1787/9789264113824-en.

OECD (2008b), Tertiary Education for the Knowledge Society: Vol. 1 and Vol. 2, OECD Publishing, http://dx.doi.org/10.1787/9789264046535-en.

OECD (2008c), Environmental Performance Reviews: Hungary, OECD Publishing, http://dx.doi.org/10.1787/9789264049284-en.

OECD and Statistics Canada (2011), Literacy for Life: Further Results from the Adult Literacy and Life Skills Survey, OECD Publishing, http://dx.doi.org/10.1787/9789264091269-en.

Paci, P., E. Tiongson, M. Walewski, J. Liwinski and M. Stoilkova (2007), "Internal Labor Mobility in Central Europe and the Baltic Region", World Bank Working Papers, No. 105, World Bank, http://dx.doi.org/10.1596/978-0-8213-7090-2. 
Persson, J. and D. Song (2010), “The Land Transport Sector: Policy and Performance", OECD Economics Department Working Papers, No. 817, OECD Publishing, http://dx.doi.org/10.1787/5km3702v78d6en.

Pina, Á. (2014), "Enhancing Competition and the Business Environment in Hungary", OECD Economics Department Working Papers, forthcoming.

Quintini, G. (2011), “Right for the Job: Over-Qualified or Under-Skilled?”, OECD Social, Employment and Migration Working Papers, No. 120, OECD Publishing, http://dx.doi.org/10.1787/5kg59fcz3tkd-en.

Randstat (2012), "Into the Gap: Exploring Skills and Mismatches", SEO Report, No. 2011-56, SEO Economic Research.

Scharle, A. and B. Váradi (2009), "A Területileg Differenciált Minimálbér Indokoltságának Vizsgálata" (Evaluating the justification for a regionally differentiated minimum wage), Budapest Institute.

SEEMIG (2013), "South East Europe and Hungary - Migratory Trends", Press material for the press conference on 22 May.

Semjén, A. (2013), "Költségmegosztás a felsőoktatásban - Utak és tévutak" (Cost-sharing in higher education - Good and bad routes), MTA KRTK (Hungarian Academy of Science) Közgazdaságtudományi Intézet.

State Audit Office (2012a), “Audit of the State Subsidy System of Rail Transport”, Report No. 1292 (full text in Hungarian).

State Audit Office (2012b), "Audit on the Effectiveness of the Measures Aimed at the Renovation, Repair and Maintenance of State-Owned Public Roads and on the Effect of These Measures on the Condition of State-Owned Public Roads", Report No. 1291 (full text in Hungarian).

Strauss, H. and C. de la Maisonneuve (2007), "The Wage Premium on Tertiary Education: New Estimates for 21 OECD Countries", OECD Economics Department Working Papers, No. 589, OECD Publishing, http://dx.doi.org/10.1787/033568367526.

Varga, J. (2013), "Labour Market Success of Hungarian Higher Education Graduates in 2011", in Hungarian Graduates 2011, Educatio Public Services, Ministry for Human Resources. 


\section{WORKING PAPERS}

The full series of Economics Department Working Papers can be consulted at www.oecd.org/eco/workingpapers

1121. Local public finances and municipal reform in Finland (June 2014) by Christophe André and Clara Garcia

1120. The economic consequences of ageing: the case of Finland (June 2014) by Christine de la Maisonneuve, Christophe André, Clara Garcia and Vincent Koen

1119. Making the most of skills in Denmark

(June 2014) by Stéphanie Jamet and Vincent Koen

1118. Trade specialisation and policies to foster competition and innovation in Denmark (June 2014) by Müge Adalet McGowan

1117. Policies for making the Chilean labour market more inclusive (June 2014) by Aida Caldera Sanchez

1116. Spillover effects from exiting highly expansionary monetary policies

(May 2014) by Łukasz Rawdanowicz, Romain Bouis, Jérôme Brezillon, Ane Kathrine Christensen and Kei-Ichiro Inaba

1115. Economic policies and microeconomic stability: a literature review and some empirics (April 2014) by Paula Garda and Volker Ziemann

1114. How to improve Israel's health-care system (April 2014) by Philip Hemmings

1113. How to improve taxes and transfers in Israel (April 2014) by Philip Hemmings

1112. New evidence on the determinants of industrial specialisation (April 2014) by Asa Johansson and Eduardo Olaberria

1111. Economic growth from the household perspective: GDP and income distribution developments across OECD countries (April 2014) by Orsetta Causa, Sonia Araujo, Agnès Cavaciuti, Nicolas Ruiz and Zuzana Smidova

1110. Would a growth slowdown in emerging markets spill over to high-income countries? A quantitative assessment (April 2014) By Patrice Ollivaud, Elena Rusticelli and Cyrille Schwellnus

1109. Short-term indicator models for quarterly GDP growth in the BRIICS: A small-scale bridge model approach (April 2014) by Thomas Chalaux and Cyrille Schwellnus

1108. The prudential regulation of financial institutions: why regulatory responses to the crisis might not prove sufficient (March 2014) by William R. White 
1107. OECD forecasts during and after the financial crisis: a post mortem (March 2014) by Nigel Pain, Christine Lewis, Thai-Thanh Dang, Yosuke Jin and Pete Richardson

1106. Fairly sharing the social impact of the crisis in Greece (January 2014) by Vassiliki Koutsogeorgopoulou, Manos Matsaganis, Chrysa Leventi and Jan-David Schneider

1105. Dividing the pie in Brazil: income distribution, social policies and the new middle class (January 2014) by Jens M. Arnold and João Jalles

1104. New indicators of competition law and policy in 2013 for OECD and non-OECD countries (December 2013) by Enrico Alemani, Caroline Klein, Isabell Koske, Cristiana Vitale and Isabelle Wanner

1103. The effect of government debt, external debt and their interaction on OECD interest rates (December 2013) by David Turner and Francesca Spinelli

1102. The state of the banking sector in Europe

(December 2013) by Dirk Schoenmaker and Toon Peek

1101. Getting Irish youth on the job track

(December 2013) by Alberto González Pandiella

1100. New econometric estimates of long-term growth effects of different areas of public spending (December 2013) by Omar Barbiero and Boris Cournède

1099. Cross-country spillovers from fiscal consolidations

(December 2013) by Antoine Goujard

1098. Informal employment in Russia: definitions, incidence, determinants and labour market segmentation

(December 2013) by Hartmut Lehmann and Anzelika Zaiceva

1097. Capacity needs in the automobile industry in the short- to medium run (November 2013) by Caroline Klein and Isabell Koske

1096. Environmental policies and productivity growth - a critical review of empirical findings (November 2013) by Tomasz Koźluk and Vera Zipperer

1095. Green growth challenges and the need for an energy reform in Mexico (November 2013) by Carla Valdivia de Richter

1094. From bricks to brains: increasing the contribution of knowledge-based capital to growth in Ireland

(November 2013) by David Haugh 